\title{
Control of Surface Defects in ZnO Nanorod Arrays with Thermally Deposited Au Nanoparticles for Perovskite Photovoltaics
}

Tulus, ${ }^{\dagger, \dagger}$ Selina Olthof, ${ }^{\S \odot}$ Magdalena Marszalek, ${ }^{\dagger}$ Andreas Peukert, ${ }^{\dagger}$ Loreta A. Muscarella, $^{\| \odot}$

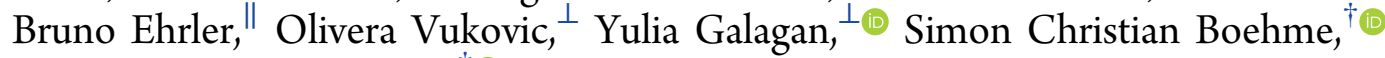
and Elizabeth von Hauff* ${ }^{*}+$ (C)

\footnotetext{
${ }^{\dagger}$ Physics of Energy, Department of Physics \& Astronomy, Faculty of Sciences, Vrije Universiteit Amsterdam, 1081 HV Amsterdam, The Netherlands

${ }^{\ddagger}$ Laboratory of Technology for Polymer, Agency for the Assessment and Application of Technology (BPPT), Jakarta 10340, Indonesia

${ }^{\S}$ Institute of Physical Chemistry, University of Cologne, Cologne 50937, Germany

"Center for Nanophotonics, AMOLF, Science Park 104, 1098 XG Amsterdam, The Netherlands

${ }^{{ }^{\perp}}$ TNO - Solliance, 5656 AE Eindhoven, The Netherlands
}

\section{Supporting Information}

\begin{abstract}
In this work, we employ vacuum deposited Au nanoparticles $(\sim 4 \mathrm{~nm})$ to control the defect density on the surface of hydrothermally synthesized $\mathrm{ZnO}$ nanorod arrays (ZnO-NR), which are of interest for electron-transport layers in perovskite solar cells. Using a combination of photoluminescence spectroscopy, X-ray photoelectron spectroscopy, and ultraviolet photoelectron spectroscopy, we show that the $\mathrm{Au}$ particles reduce the presence of defects in the $\mathrm{ZnO}-\mathrm{NR}$. We discuss this in terms of trap filling due to band bending at the $\mathrm{ZnO}-\mathrm{NR}$ surface. As a proof-of-concept, we apply the Audecorated $\mathrm{ZnO}-\mathrm{NR}$ as electron-transport layers in mixed-cation and mixed-halide lead perovskite solar cells

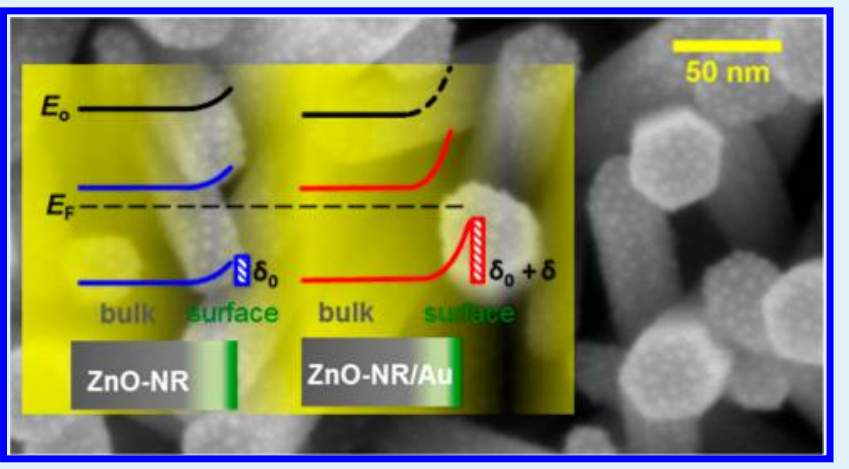
$\left(\mathrm{Cs}_{0.15} \mathrm{FA}_{0.85} \mathrm{PbI}_{2.75} \mathrm{Br}_{0.25}\right)$. Devices prepared with the $\mathrm{Au}$ decorated $\mathrm{ZnO}$-NR electron-transport layers demonstrate higher open-circuit voltages and fill factors compared to solar cells prepared with pristine $\mathrm{ZnO}-\mathrm{NR}$, resulting in an increase in the power-conversion efficiency from 11.7 to $13.7 \%$. However, the operational stability of the solar cells is not improved by the Au nanoparticles, indicating that bulk properties of the perovskite may limit device lifetime.
\end{abstract}

KEYWORDS: transport layer, $\mathrm{ZnO}$ nanostructures, perovskite photovoltaics, mixed cation, mixed halide, interface, defects, photoelectron spectroscopy

\section{INTRODUCTION}

Perovskite photovoltaics has seen unprecedented progress in reported power-conversion efficiencies since 2009. ${ }^{1-3}$ Perovskites used in photovoltaics have the crystal structure of $\mathrm{ABX}_{3}$, where $A$ is a cation (such as methylammonium (MA, $\mathrm{CH}_{3} \mathrm{NH}_{3}^{+}$), formamidinium (FA, $\left.\mathrm{CH}_{3}\left(\mathrm{NH}_{2}\right)_{2}^{+}\right), \mathrm{Cs}^{+}$, or $\mathrm{Rb}^{+}$), $\mathrm{B}$ is a divalent metal ion ( such as $\mathrm{Pb}^{2+}$ or $\mathrm{Sn}^{2+}$ ), and $\mathrm{X}$ is a halide ( such as $\mathrm{I}^{-}, \mathrm{Br}^{-}$, or $\mathrm{Cl}^{-}$). ${ }^{3-7}$ Recent breakthroughs in efficiency have been achieved with mixed-cation and mixedanion perovskites. ${ }^{3-8}$ Besides perovskite composition, device interfaces are widely recognized as a bottleneck for both efficiency and stability. ${ }^{6,9-13}$ In particular, recent reports have highlighted the need for developing high-performance electron-transport layers $(\mathrm{ETL})^{14,15}$ to reduce interfacial recombination losses that ultimately limit solar-cell efficiency. $^{16,17}$
The use of $\mathrm{ZnO}$ as an ETL for emerging thin-film photovoltaics offers a wide range of potential advantages. $\mathrm{ZnO}$ is a wide bandgap semiconductor with high electron mobility, with reported values of $200-300 \mathrm{~cm}^{2} \mathrm{~V} \mathrm{~s}^{-1}$ for bulk material and $\sim 1000 \mathrm{~cm}^{2} \mathrm{~V} \mathrm{~s}^{-1}$ for single-crystal nanowires ${ }^{18-20}$ and suitable energy levels for efficient extraction of electrons. $^{21,22}$ Despite these advantages, $\mathrm{ZnO}$ is currently not widely used in perovskite solar cells ${ }^{23-27}$ compared to other ntype metal oxides, such as, for example, $\mathrm{TiO}_{2}, \mathrm{SnO}_{2}$, and $\mathrm{NiO}_{x},{ }^{26-29}$ likely because of issues of decomposition of the perovskite film in first generation $\mathrm{ZnO} / \mathrm{MAPbI}_{3}$ structures. ${ }^{30,31}$ Additionally, the complex nature of crystal defects in $\mathrm{ZnO}$

Received: March 2, 2019

Accepted: April 26, 2019

Published: April 26, 2019 


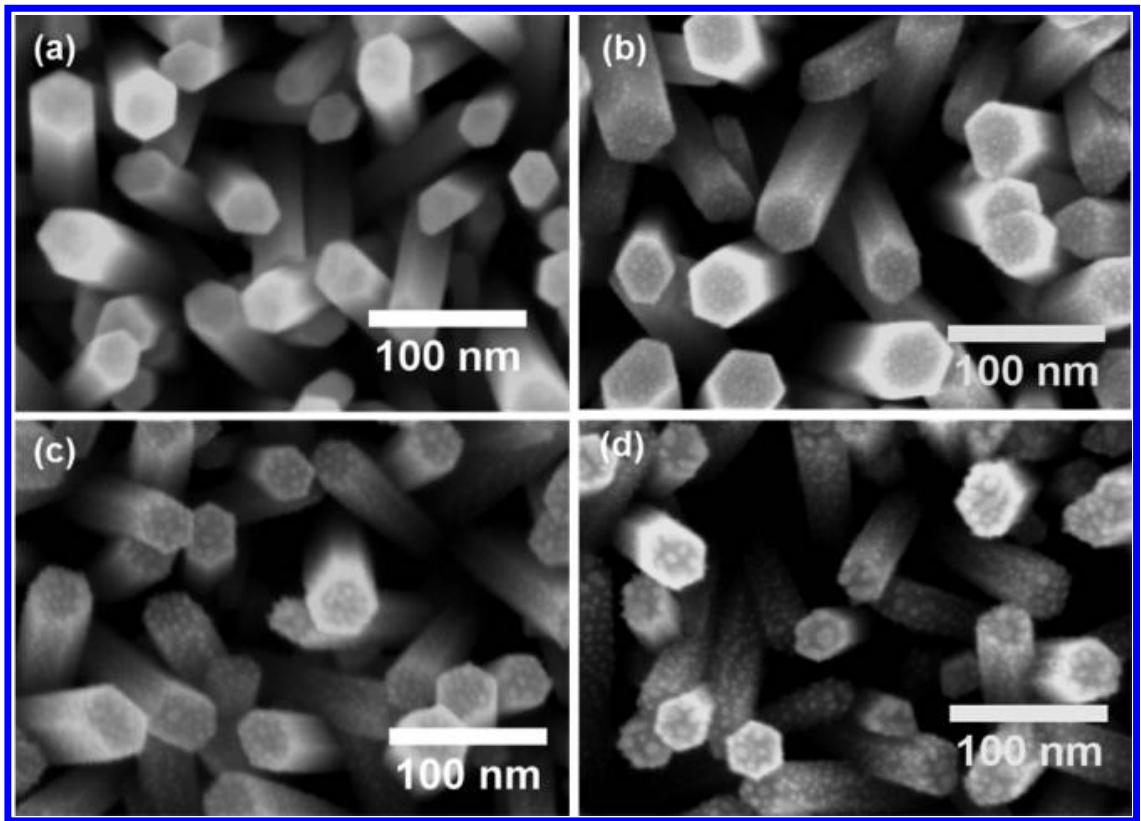

Figure 1. Top-view SEM images of (a) $\mathrm{ZnO}$ nanorods ( $\mathrm{ZnO}-\mathrm{NR}$ ), (b) $0.4 \mathrm{~nm}$ Au-decorated $\mathrm{ZnO}$ nanorods ( $\mathrm{ZnO}-\mathrm{NR} / 0.4 \mathrm{Au}),(\mathrm{c})$ 0.8 nm Audecorated $\mathrm{ZnO}$ nanorods $(\mathrm{ZnO}-\mathrm{NR} / 0.8 \mathrm{Au}$ ), and (d) $1.2 \mathrm{~nm}$ Au-decorated $\mathrm{ZnO}$ nanorods $(\mathrm{ZnO}-\mathrm{NR} / 1.2 \mathrm{Au})$.

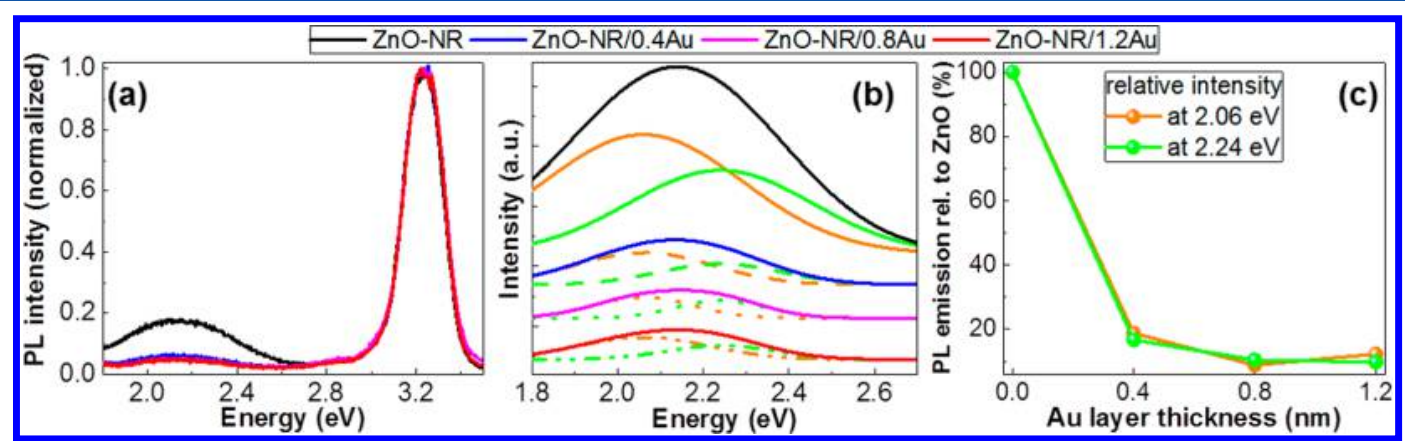

Figure 2. (a) $\mathrm{PL}$ spectra of the $\mathrm{ZnO}-\mathrm{NR}$ (black solid line), $\mathrm{ZnO}-\mathrm{NR} / 0.4 \mathrm{Au}$ (blue solid line), $\mathrm{ZnO}-\mathrm{NR} / 0.8 \mathrm{Au}$ (pink solid line), and $\mathrm{ZnO}-\mathrm{NR} /$ $1.2 \mathrm{Au}$ (red solid line). (b) Zoom of (a), the defect PL region, where each data set has been fit with two Gaussian distributions, one centered at 2.24 $\mathrm{eV}$ (green lines, corresponding to the "green luminescence" in $\mathrm{ZnO}$ ) and one centered at $2.06 \mathrm{eV}$ (orange lines, corresponding to the "orange luminescence" in $\mathrm{ZnO}$ ). Fits of the $\mathrm{ZnO}-\mathrm{NR}, \mathrm{ZnO}-\mathrm{NR} / 0.4 \mathrm{Au}, \mathrm{ZnO}-\mathrm{NR} / 0.8 \mathrm{Au}$, and $\mathrm{ZnO}-\mathrm{NR} / 1.2 \mathrm{Au}$ are shown as solid, dashed, dotted, and dashed dotted lines, respectively. Traces were plotted with vertical offsets to enhance clarity. (c) The PL emission relative to the ZnO-NR substrate at $2.06 \mathrm{eV}$ (orange) and at $2.24 \mathrm{eV}$ (green) as a function of Au coverage.

films and nanostructures has generally limited its application in optoelectronic devices. $^{21,32}$

Decorating $\mathrm{ZnO}$ with $\mathrm{Au}$ nanoparticles is an intriguing strategy to both passivate the prominent surface defects in $\mathrm{ZnO}$ and to increase light absorption in the solar-cell active layer via near-field plasmonic enhancement or light scattering. ${ }^{33-37}$ Some publications have demonstrated that decorating $\mathrm{ZnO}$ nanostructures with $\mathrm{Au}$ nanoparticles quenches green emission from defect states in the $\mathrm{ZnO}$ while simultaneously increasing photocatalytic activity. ${ }^{37-45}$ However, the underlying mechanisms and electronic interactions between $\mathrm{ZnO}$ and $\mathrm{Au}$ are not well-understood. ${ }^{37,46,47}$

Here we investigate the influence of $\mathrm{Au}$ nanoparticles on the surface defects and properties of $\mathrm{ZnO}-\mathrm{NR}$. These $\mathrm{ZnO}-\mathrm{NR}$ are prepared via chemical bath deposition, whereas the $\mathrm{Au}$ nanoparticles are subsequently formed by thermally evaporating $\mathrm{Au}$ onto the $\mathrm{ZnO}-\mathrm{NR}$, resulting in small $(\sim 4 \mathrm{~nm})$, evenly distributed $\mathrm{Au}$ nanoparticles. The deposition of $\mathrm{Au}$ particles via thermal deposition, instead of wet chemical methods, reduces unwanted chemical residue on the $\mathrm{ZnO}$ surface. Using photoluminescence (PL) spectroscopy, we find that Audecorated $\mathrm{ZnO}-\mathrm{NR}(\mathrm{ZnO}-\mathrm{NR} / \mathrm{Au})$ exhibit a decreased emission from surface defects compared to pristine $\mathrm{ZnO}-\mathrm{NR}$. This is in excellent agreement with observations from impedance spectroscopy and X-ray photoelectron spectroscopy (XPS), which show a reduction in the density of trap states at the $\mathrm{ZnO}-\mathrm{NR} / \mathrm{Au} /$ perovskite interface and a reduction in surface defect density, respectively. Finally, UV photoelectron spectroscopy (UPS) correlates these results with an increase in band bending at the $\mathrm{ZnO}-\mathrm{NR}$ surface because of $\mathrm{Au}$, leading to the effective filling of these surface states. As a proof-ofconcept, we test the performance of mixed-cation and mixedhalide lead perovskite solar cells $\left(\mathrm{Cs}_{0.15} \mathrm{FA}_{0.85} \mathrm{PbI}_{2.75} \mathrm{Br}_{0.25}\right)^{48,49}$ prepared with $\mathrm{ZnO}-\mathrm{NR} / \mathrm{Au}$ transport layers. Solar cells prepared with $\mathrm{ZnO}-\mathrm{NR} / \mathrm{Au}$ transport layers initially show higher fill factors $(\mathrm{FF})$ and open-circuit voltages $\left(V_{\text {oc }}\right)$, leading to higher power-conversion efficiencies (PCE) than solar cells prepared with pristine $\mathrm{ZnO}-\mathrm{NR}$. However, we observe that the $\mathrm{Au}$ nanoparticles do not improve the operational stability of the perovskite solar cells under continuous light soaking. These 


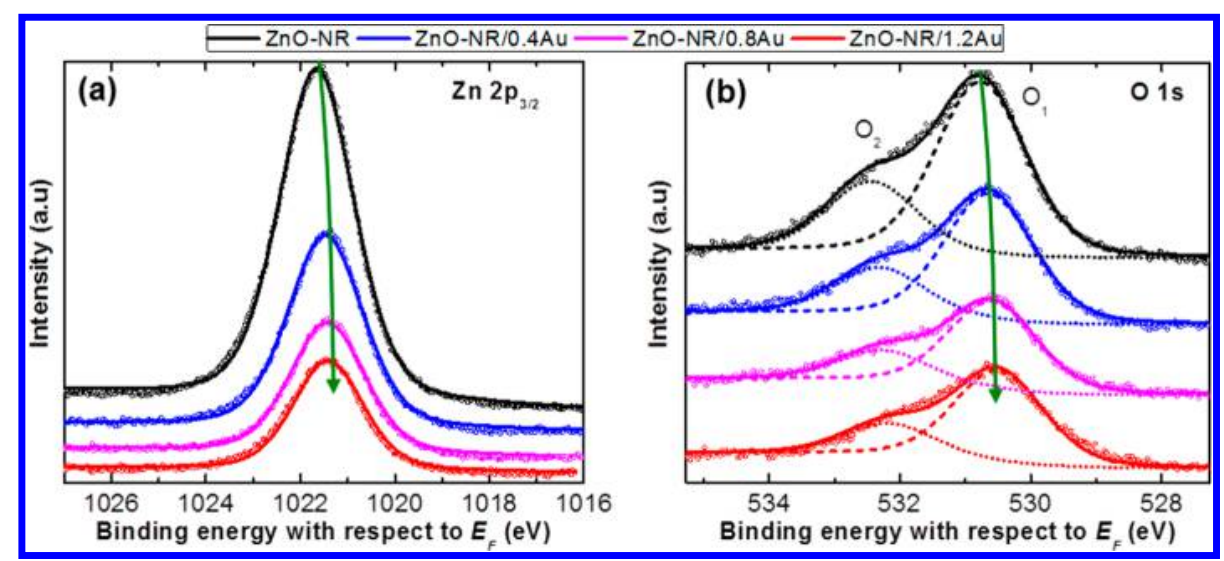

Figure 3. XPS spectra of $\mathrm{ZnO}-\mathrm{NR}$ (black), $\mathrm{ZnO}-\mathrm{NR} / 0.4 \mathrm{Au}$ (blue), $\mathrm{ZnO}-\mathrm{NR} / 0.8 \mathrm{Au}$ (pink), and $\mathrm{ZnO}-\mathrm{NR} / 1.2 \mathrm{Au}$ (red). (a) shows the $\mathrm{Zn} 2 \mathrm{p}_{3 / 2}$ region, and (b) shows the $\mathrm{O} 1 \mathrm{~s}$ region. Here, two contributions are fitted into the $\mathrm{O}$ 1s region: $O_{1}$ (dashed lines) represents oxygen signal from $\mathrm{ZnO}$, and $\mathrm{O}_{2}$ (dotted lines) represents surface $-\mathrm{OH}$ groups. Open symbols mark the measurements, whereas solid lines are fits to the data; the data sets are stacked via vertical offsets to enhance clarity.

results indicate that the operational stability of these solar cells is not only limited by defect states at the ETL interface. $^{27,37,46,47,50,51}$

\section{RESULTS AND DISCUSSION}

II.i. Surface Defect Passivation in Au-Decorated ZnO Nanorods. $\mathrm{ZnO}-\mathrm{NR}$ and $\mathrm{ZnO}-\mathrm{NR} / \mathrm{Au}$ samples were fabricated according to the procedure described in the Experimental Section. Briefly, ZnO-NR were deposited using chemical bath deposition (CBD) via $\mathrm{ZnO}$ seeding on ITO substrates. $^{52-54}$ Decoration of the $\mathrm{ZnO}-\mathrm{NR}$ with $\mathrm{Au}$ nanoparticles was achieved by thermally depositing a thin Au layer on top of the nanorods with the sample kept at room temperature, leading to the formation of small $(<10 \mathrm{~nm})$ individual $\mathrm{Au}$ nanoparticles distributed over the $\mathrm{ZnO}-\mathrm{NR}$ array. We investigated $\mathrm{ZnO}-\mathrm{NR} / \mathrm{Au}$ samples prepared with $\mathrm{Au}$ effective layer thicknesses of $0.4,0.8$, and $1.2 \mathrm{~nm}$.

Figure $1(\mathrm{a}-\mathrm{d})$ shows the top-view scanning electron microscopy (SEM) images of $\mathrm{ZnO}-\mathrm{NR}$ and $\mathrm{ZnO}-\mathrm{NR}$ decorated with $\mathrm{Au}$ at effective layer thicknesses of $0.4 \mathrm{~nm}$ $(\mathrm{ZnO}-\mathrm{NR} / 0.4 \mathrm{Au}), 0.8 \mathrm{~nm}(\mathrm{ZnO}-\mathrm{NR} / 0.8 \mathrm{Au})$, and $1.2 \mathrm{~nm}$ $(\mathrm{ZnO}-\mathrm{NR} / 1.2 \mathrm{Au})$, respectively. The $\mathrm{ZnO}$ nanorods are 410 $\mathrm{nm}$ long (see Figure S1(b)), and the distribution of $\mathrm{Au}$ nanoparticles on the nanorod surface appears homogeneous. From the SEM images, we estimate the diameter of the $\mathrm{Au}$ nanoparticles to be approximately $4 \pm 1.2 \mathrm{~nm}$, and we cannot identify differences in the $\mathrm{Au}$ nanoparticle size between the samples.

Figure 2(a) shows the PL spectra of the $\mathrm{ZnO}-\mathrm{NR}$ (black solid line), $\mathrm{ZnO}-\mathrm{NR} / 0.4 \mathrm{Au}$ (blue solid line), $\mathrm{ZnO}-\mathrm{NR} / 0.8 \mathrm{Au}$ (pink solid line), and $\mathrm{ZnO}-\mathrm{NR} / 1.2 \mathrm{Au}$ (red solid line), excited at $4.43 \mathrm{eV}$ and normalized to the $\mathrm{ZnO}-\mathrm{NR}$ emission at $3.23 \mathrm{eV}$ (see also Figure S2(c)). The emission at around $2 \mathrm{eV}$ originates from defects in the bandgap of the $\mathrm{ZnO}$ $\mathrm{NR},{ }^{50,51,55-57}$ and our measurements show that the relative intensity of this defect emission is lower in the $\mathrm{ZnO}-\mathrm{NR} / \mathrm{Au}$ samples compared to the $\mathrm{ZnO}-\mathrm{NR}$ samples (see also Figure S2(c)). In Figure 2(b), we used two Gaussian contributions to fit the area of defect emission in the PL spectra; here the peak centers, heights, and widths were used as fitting parameters. This approach consistently yields two features, one centered at $2.06 \mathrm{eV}$ (orange) (i.e., "orange emission" in $\mathrm{ZnO}$ ) and one centered at $2.24 \mathrm{eV}$ (green) (i.e., "green emission" in $\mathrm{ZnO}){ }^{58}$
Figure 2(c) shows the decrease (in percentage) of the defect emission at $2.06 \mathrm{eV}$ (orange) and at $2.24 \mathrm{eV}$ (green) as a function of effective $\mathrm{Au}$ thickness. The Au nanoparticles lead to a decrease in both green and orange emission from the $\mathrm{ZnO}$ by approximately $90 \%$. Specifically, the green emission decreases by 83,89 , and $90 \%$, and the orange emission decreases by 81,91 , and $87 \%$ for $\mathrm{Au}$ effective thicknesses of $0.4,0.8$, and $1.2 \mathrm{~nm}$, respectively.

The intricate nature of $\mathrm{ZnO}$ defects has been intensively investigated in the literature. ${ }^{21,32,47,55-58}$ Green emission is widely observed in $\mathrm{ZnO}$ fabricated using a variety of different protocols and is attributed to oxygen vacancies $\left(V_{o}\right) .^{21,32,55,56,57,59}$ Orange emission, on the other hand, is commonly observed in hydrothermally synthesized $\mathrm{ZnO}$ and has been attributed to interstitial oxygen ions. ${ }^{55-59}$ Our PL measurements suggest that $\mathrm{Au}$ nanoparticles suppressed both oxygen vacancies and interstitials. ${ }^{55-59}$ We can infer that these defects predominantly reside at the surface, given the significant passivation by surface-bound $\mathrm{Au}$ nanoparticles. This is consistent with the increasing suppression of the green emission with increasing Au effective thickness.

We would like to point out that our classification of the observed defects as oxygen interstitials and oxygen vacancies is motivated by considerations of bulk $\mathrm{ZnO}{ }^{2,32}$ Likely, we oversimplify the intricate nature of defects at $\mathrm{ZnO}-\mathrm{NR}$ surfaces, as recent reports have suggested rich defect physics arising from surfactants, significant surface reconstructions, and concomitantly altered defect landscapes. ${ }^{60,61}$ However, our approach is corroborated by the surprisingly similar spectral features of the defect $\mathrm{PL}$ of bulk $\mathrm{ZnO}$ and our $\mathrm{ZnO}$ nanorods (i.e., both exhibit the typical green and orange PL).

Next, XPS and UPS were employed to learn more about the modification of the $\mathrm{ZnO}-\mathrm{NR}$ surface composition and energetics because of the $\mathrm{Au}$ coverage. Figure 3 shows the XPS signals of the (a) $\mathrm{Zn} 2 \mathrm{p}_{3 / 2}$ and (b) $\mathrm{O}$ 1s core levels for $\mathrm{ZnO}-\mathrm{NR}$ (black), $\mathrm{ZnO}-\mathrm{NR} / 0.4 \mathrm{Au}$ (blue), $\mathrm{ZnO}-\mathrm{NR} / 0.8 \mathrm{Au}$ (pink), and $\mathrm{ZnO}-\mathrm{NR} / 1.2 \mathrm{Au}$ (red). The $\mathrm{Zn} 2 \mathrm{p}_{3 / 2}$ signals in Figures 3(a) can be well-described by a single mixed Gaussian/ Lorentzian peak, indicating that $\mathrm{Zn}$ is present in the +2 oxidation state. The oxygen 1s signals in Figure 3(b) can be fit with two contributions, one attributed to oxygen bound in $\mathrm{ZnO}\left(\mathrm{O}_{1}\right)$ and one attributed to surface $-\mathrm{OH}$ groups $\left(\mathrm{O}_{2}\right)$. First, looking at the relative peak intensities and correcting 

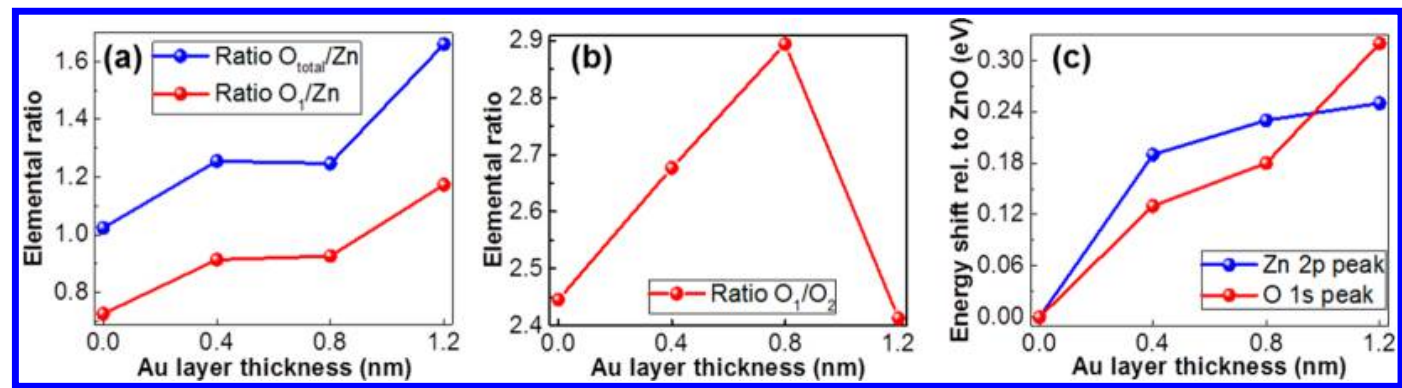

Figure 4. Values extracted from the XPS measurements for varying effective Au thicknesses of the ZnO-NR/Au samples. (a) Ratio of the peak areas of $O_{\text {total }}$ to $\mathrm{Zn}$ (blue) and $O_{1}$ to $\mathrm{Zn}$ (red). (b) Ratio of $O_{1}$ to $O_{2}$, where $O_{1}$ represents $\mathrm{O}$ in $\mathrm{ZnO}$, and $O_{2}$ represents surface $-\mathrm{OH}$ groups, respectively. (c) Relative shift of the $\mathrm{Zn} 2 \mathrm{p}$ (blue) and $\mathrm{O} 1 \mathrm{~s}$ peak (red) toward lower binding energies, with respect to the $\mathrm{ZnO}-\mathrm{NR}$ sample without $\mathrm{Au}$.

them for their relative sensitivity factors (see Experimental Section), we can extract the elemental composition of the surface. In Figure 4(a), the ratio of the total oxygen signal $\left(O_{1}\right.$ $+\mathrm{O}_{2}$ ) to that of $\mathrm{Zn}$ is shown in blue, and the ratio between $O_{1}$ and $\mathrm{Zn}$ is plotted in red. We clearly observe that an increasing $\mathrm{Au}$ effective layer thickness leads to a relative decrease in the $\mathrm{Zn}$ signal with respect to the oxygen signal. The $O_{1}$ excess is increased by 26,28 , and $62 \%$ for $\mathrm{ZnO}-\mathrm{NR} / 0.4 \mathrm{Au}, \mathrm{ZnO}-\mathrm{NR} /$ $0.8 \mathrm{Au}$, and $\mathrm{ZnO}-\mathrm{NR} / 1.2 \mathrm{Au}$, respectively, compared to $O_{1}$ excess in pristine $\mathrm{ZnO}-\mathrm{NR}$. This means that $\mathrm{Au}$ nanoparticles either preferably bind to the surface $\mathrm{Zn}$ sites, thereby covering them and rendering them unobservable, and/or induce a change in surface termination, by which the effective amount of oxygen at the surface is increased. The second scenario agrees with our finding of a decrease in defect PL, thereby supporting the hypothesis that $\mathrm{Au}$ leads to a reduction in surface oxygen vacancies. Figure 4 (b) shows the related change in the ratio between the two different oxygen contributions, $\mathrm{O}_{1} / \mathrm{O}_{2}$ vs Au coverage. Here we observe a clear increase in the $\mathrm{ZnO}$-related $\mathrm{O}_{1}$ peak with respect to the defective $\mathrm{OH}$-related $\mathrm{O}_{2}$ up to a coverage of $0.8 \mathrm{~nm}$. At this moment, it is unclear why the $1.2 \mathrm{~nm}$ value does not follow this trend, possibly because the gold becomes more reactive to oxygen at a certain size or the gold particles at a certain size coalesce differently. ${ }^{40}$ More specifically, Figure 4 shows that in the case of the oxygen vacancy defects $\left(O_{1}\right)$, we observe a clear trend in the reduction of defects with increasing Au coverage, whereas this trend is not as clear for the defects related to $\mathrm{OH}$ groups $\left(\mathrm{O}_{2}\right)$. Note that the lowest defect density in this case is found for $\mathrm{ZnO}$ $\mathrm{NR} / 0.8 \mathrm{Au}$ (highest $\mathrm{O}_{1} / \mathrm{O}_{2}$ ratio), whereas the highest is found for $\mathrm{ZnO}-\mathrm{NR} / 1.2 \mathrm{Au}$. This may indicate that above a certain threshold, Au particles aggregate more strongly, possibly leaving larger areas of the surface uncovered. Our results suggest that $\mathrm{Au}$ deposition correlates with decreasing $\mathrm{Zn} / \mathrm{O}$ excess in our nanorods. That finding would be consistent with either Au replacing (surface) $\mathrm{Zn}$ or attracting additional $\mathrm{O}$ into the $\mathrm{ZnO}$ lattice.

In addition, XPS can give information on the changes in Fermi level position within the band gap close to the surface, as core level peaks follow energy shifts experienced by the valence band density of states. Clear shifts are observed in the positions of the $\mathrm{Zn}$ - and O-related peaks, as indicated in Figure 3 by the green arrows. The respective changes in binding energy, relative to the pristine $\mathrm{ZnO}$-NR substrate, are shown in Figure 4(c). Here, changes toward lower binding energy by approximately $290 \pm 40 \mathrm{meV}$ of the $\mathrm{Zn} 2 \mathrm{p}$ (blue) and $\mathrm{O} 1 \mathrm{~s}$ (red) peaks are observed with increasing effective Au thickness.
In contrast to the strongly bound states probed by XPS, UPS gives information on the weakly bound valence band (VB) density of states (DOS), which are shown in Figure 5(a)

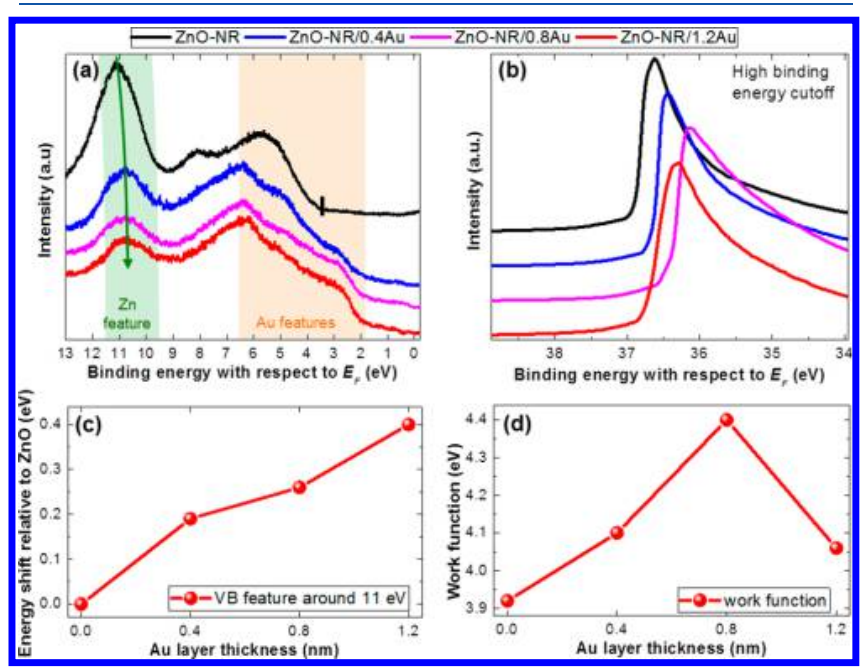

Figure 5. (a) UPS spectra of the VB regions of $\mathrm{ZnO}-\mathrm{NR}$ (black solid line), $\mathrm{ZnO}-\mathrm{NR} / 0.4 \mathrm{Au}$ (blue solid line), $\mathrm{ZnO}-\mathrm{NR} / 0.8 \mathrm{Au}$ (pink solid line), and $\mathrm{ZnO}-\mathrm{NR} / 1.2 \mathrm{Au}$ (red solid line). The $\mathrm{VB}$ onset of $\mathrm{ZnO}-\mathrm{NR}$ is indicated by the vertical mark at $3.45 \mathrm{eV}$, and the shift of a characteristic feature of $\mathrm{ZnO}$ is indicated by the green arrow. (b) Corresponding UPS spectra in the region of the high-binding-energy cutoff. The scans in (a) and (b) are offset vertically to enhance clarity. (c) Shift of the binding energy of the $\mathrm{ZnO}$-related VB feature (green arrow in subfigure a) relative to the bare $\mathrm{ZnO}-\mathrm{NR}$ substrate upon increasing $\mathrm{Au}$ coverage. (d) Change in $W_{\mathrm{f}}$ as a function of $\mathrm{Au}$ coverage.

measured by $\mathrm{He}_{\alpha}$ excitation; furthermore, the work function $\left(W_{\mathrm{f}}\right)$ can be extracted from the high-energy electron cutoff (see Figure 5(b)). Changes observed in the VB density of states with increasing $\mathrm{Au}$ coverage mostly originate from the growing $\mathrm{Au}$ contribution, which has characteristic features around 3 and $6 \mathrm{eV}$ (shaded orange area). As a result of the $\mathrm{Au}$ $\mathrm{DOS}$, the onset of the $\mathrm{ZnO}$ DOS cannot be read out, except in the case of zero coverage, where it is marked by a vertical black line at $3.45 \mathrm{eV}$ with respect to the Fermi energy. Still, we can deduce changes induced to the $\mathrm{ZnO}-\mathrm{NR}$ surface by the $\mathrm{Au}$ coverage using the characteristic $\mathrm{ZnO}-\mathrm{NR}$ feature at $11 \mathrm{eV}$ to track shifts. This feature is marked by a green arrow in Figure 5(a), and the corresponding binding-energy shift in relation to the Au coverage is plotted in Figure 5 (c). In UPS, we observe a shift to lower binding energy by $400 \mathrm{meV}$ that is somewhat 


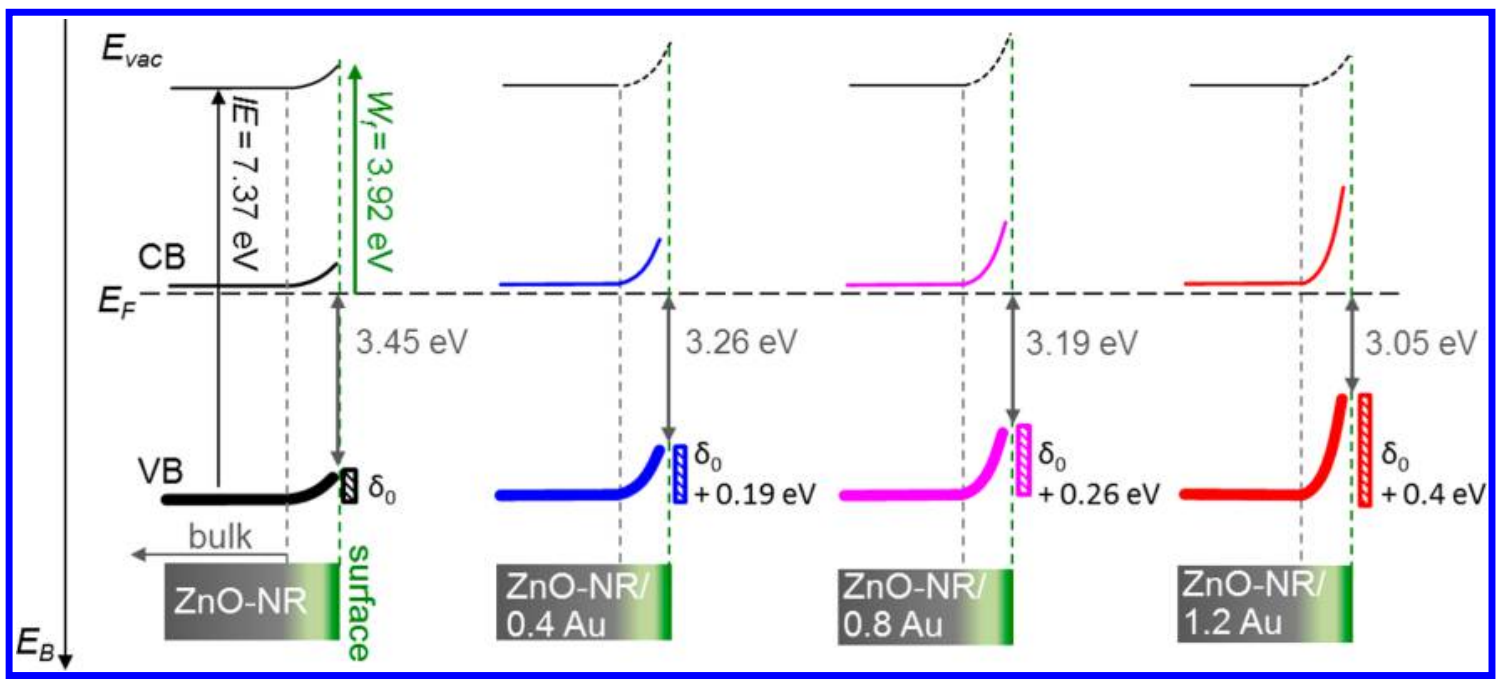

Figure 6. Schematic energy level diagrams of Au-induced band bending at the surfaces of $\mathrm{ZnO}-\mathrm{NR}$ (black), $\mathrm{ZnO}-\mathrm{NR} / 0.4 \mathrm{Au}$ (blue), $\mathrm{ZnO}-\mathrm{NR} /$ $0.8 \mathrm{Au}$ (pink), and $\mathrm{ZnO}-\mathrm{NR} / 1.2 \mathrm{Au}$ (red). Shaded areas symbolize the surface band bending as observed from the UPS measurements; already for the pristine $\mathrm{ZnO}-\mathrm{NR}$ sample an initial bend bending $\delta_{0}$ is assumed against a not further specified bulk value, as often reported in the literature. The CB band is also included (even though not directly measured in this work) assuming a position close to the Fermi energy in the bulk. The surface work function is only stated for the pristine sample, because the value is not well-defined for the inhomogeneously Au covered samples. The ionization energy (IE) of $\mathrm{ZnO}-\mathrm{NR}$ was extracted from the UPS spectra by calculating the sum of the VB onset and the $W_{\mathrm{f}}$ from Figure $5(\mathrm{a}, \mathrm{b})$.

larger than the shift in XPS; this is expected due to the higher surface sensitivity of UPS. Finally, Figure 5(b,d) shows the high-energy cutoff as well as the extracted changes in work function, respectively. We find a monotonous increase in $W_{\mathrm{f}}$ from 3.92 to $4.4 \mathrm{eV}$ up to a $\mathrm{Au}$ coverage of $0.8 \mathrm{~nm}$; however, for the thickest Au coverage, the $W_{\mathrm{f}}$ is lowered, again indicating that the surface of that sample might have been affected by additional adsorbates.

Overall, XPS and UPS measurements both show that coverage of $\mathrm{ZnO}-\mathrm{NR}$ by $\mathrm{Au}$ nanoparticles induces a shift of characteristic $\mathrm{ZnO}$ features to lower binding energies (i.e., an upward band bending of the energy levels toward the $\mathrm{ZnO}-\mathrm{NR}$ surface as sketched in Figure 6). We want to note that work function values measured on the inhomogeneous $\mathrm{Au}$ covered surfaces should be interpreted as an "effective" $W_{\mathrm{f}}$ that is somewhere in between the low $W_{\mathrm{f}}$ of $\mathrm{ZnO}$ and the high $W_{\mathrm{f}}$ of $\mathrm{Au}$ nanoparticles. ${ }^{62}$ Therefore, in Figure 6, we only give an indication of the trend by the dotted $E_{\mathrm{vac}}$ line but no actual value for the surface work function. Furthermore, we note that the band gap is not affected by Au nanoparticle coverage, as inferred from the constant energy of the PL band edge feature (see Figure $2(\mathrm{a})$ ). This suggests that the $\mathrm{CB}$ edge follows the same trend of upward band bending (see Figure 6).

Theoretical work on $\mathrm{ZnO}$ indicates that an upward shift in the Fermi level position with respect to the band edges (which corresponds to a downward shifting of the bands with respect to $E_{\mathrm{F}}$, which is the frame of reference for the experiments here) alters the formation energies for vacancies, specifically decreasing the formation energy for $\mathrm{Zn}$ vacancies and increasing the formation energy for $\mathrm{O}$ vacancies. ${ }^{32}$ Our UPS and XPS results consistently show that all characteristic energy levels shift to lower binding energies, corresponding to a shift of the Fermi level away from the conduction band.

Previously, $\mathrm{ZnO}$ nanorods have been reported to exhibit such an upward band bending at the surface (i.e., toward vacuum), for a variety of treatments, ${ }^{44,55,63}$ which is the reason why we already indicated in Figure 6 that there might be a surface contribution $\delta_{0}$ present even in the case without $\mathrm{Au}$ coverage. Upward band bending is equivalent to reduced $n$ doping at the surface ${ }^{46,47}$ (with respect to the $\mathrm{ZnO}$ nanorod bulk) and may significantly alter the optoelectronic and photocatalytic properties of $\mathrm{ZnO}$-based devices. For example, it has been suggested that the predominant defect species in $\mathrm{ZnO}$ depends on the Fermi level ${ }^{21,32}$ and that the upward band bending creates $\mathrm{V}_{\mathrm{o}}^{+}$sites capable of engaging in recombination processes with VB holes, yielding the typical green emission of $\mathrm{ZnO}{ }^{55-57,59}$ The observed increase in this surface contribution with Au coverage in Figure 6 could have two origins: (i) the $\mathrm{Au}$ nanoparticles increase the upward band bending at the $\mathrm{ZnO}$ surface by changing the defect density of the surface and thereby the Fermi level position, or (ii) in the presence of a pre-existing surface band bending of the magnitude $\delta_{0}$, the partial coverage of the $\mathrm{ZnO}$ by Au merely decreases the XPS and UPS probing depth. In the latter case, even unaltered band bending in Au-decorated $\mathrm{ZnO}$ nanorods would manifest itself as an upshift of energy levels because of increased XPS and UPS surface sensitivities. We favor interpretation (i) of the increased band bending, as interpretation (ii) cannot explain the observed quenching of the defect PL.

Our PL data (see Figure 2) suggest that coverage of the $\mathrm{ZnO}-\mathrm{NR}$ with $\mathrm{Au}$ particles can be applied to effectively reduce the density of oxygen vacancies and defects related to $\mathrm{OH}$ groups on the $\mathrm{ZnO}$ nanorod surface. The distinct binding energies of O-containing species in XPS (see Figures 3 and 4) further allow us to conclude that $\mathrm{Au}$ reduces the presence of surface $-\mathrm{OH}$ groups. Comparing the peak areas between $O_{1}$ and $\mathrm{O}_{2}$ (i.e., oxygen in $\mathrm{ZnO}$ to oxygen present as surface $-\mathrm{OH}$ groups, see Figure $4(\mathrm{~b})$ ), this ratio increases for $\mathrm{ZnO}-\mathrm{NR}$ / $0.4 \mathrm{Au}$ and $\mathrm{ZnO}-\mathrm{NR} / 0.8 \mathrm{Au}$, consistent with the $\mathrm{Au}$ nanoparticle coverage reducing the number density of surface $-\mathrm{OH}$ sites. From the PL and XPS/UPS data, we cannot distinguish between the various models proposed in the literature on the charged state of the oxygen vacancy-a single-positive charge according to Barbagiovanni et al. ${ }^{56,57}$ or the uncharged and double-positive charge according to Janotti and Van de Walle. ${ }^{21,32}$ However, we note that it is important to account 


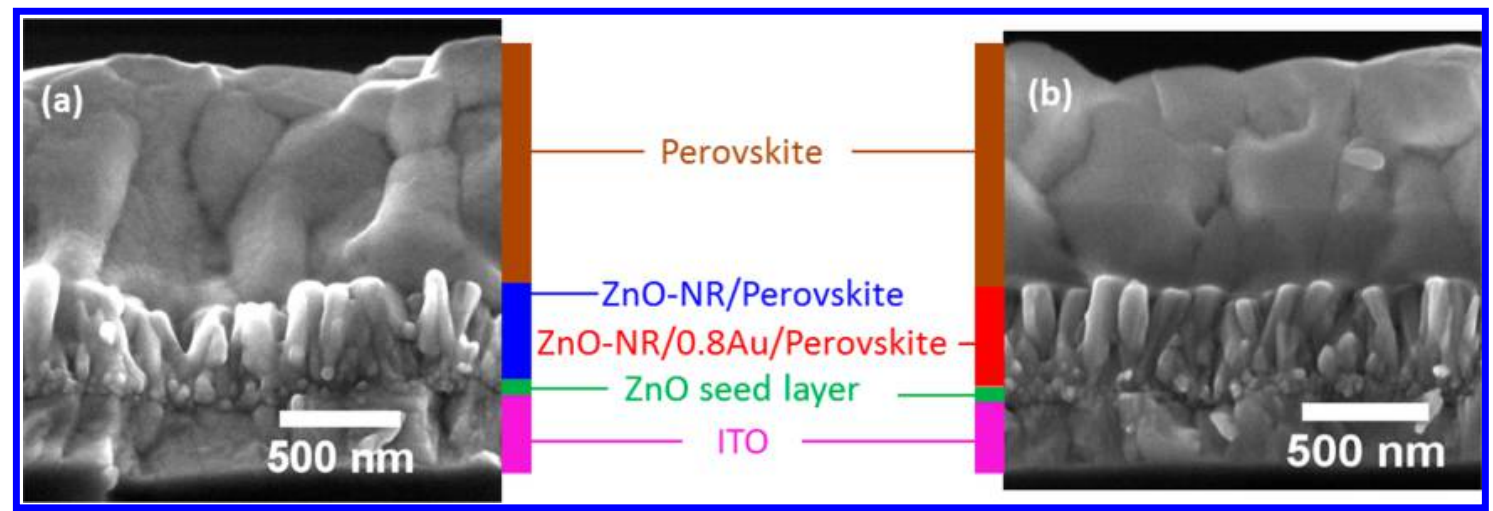

Figure 7. SEM images of perovskite deposited on $\mathrm{ZnO}-\mathrm{NR}$ (a) without $\mathrm{Au}(\mathrm{ZnO}-\mathrm{NR} /$ perovskite) and (b) with $0.8 \mathrm{~nm} \mathrm{Au}(\mathrm{ZnO}-\mathrm{NR} / 0.8 \mathrm{Au} /$ perovskite).

for band bending in any case, as green defect PL can be reduced by passivating oxygen vacancies via reduced $n$-type character at the $\mathrm{ZnO}$ surface.

Previously, Au nanostructures have been reported to either quench the green emission from $\mathrm{ZnO}$ nanostructures, correlated with increased photocatalytic activity, ${ }^{37-43}$ or enhance the green emission, via formation of trap states at the $\mathrm{Au} / \mathrm{ZnO}$ junction induced by an upward band bending and concomitant larger depletion regions within the $\mathrm{ZnO}$ layer. ${ }^{42,44,46,47}$ Our results, however, indicate that the increased upward band bending in $\mathrm{ZnO}-\mathrm{NR}$ induced by $\mathrm{Au}$ is consistent with a reduction in defect states. ${ }^{46,47}$

II.ii. Perovskite-Infiltrated ZnO Nanorod Structures. We chose pristine $\mathrm{ZnO}$ nanorod arrays and $\mathrm{ZnO}-\mathrm{NR} / 0.8 \mathrm{Au}$ samples to test as an ETL in perovskite solar cells. Figure 7 shows the SEM cross sections of the perovskite layers infiltrated in the (a) $\mathrm{ZnO}-\mathrm{NR}$ and (b) $\mathrm{ZnO}-\mathrm{NR} / 0.8 \mathrm{Au}$ samples. The samples appeared stable after thermal annealing at $100{ }^{\circ} \mathrm{C}$ for $30 \mathrm{~min}$, in contrast to former reports of $\mathrm{MAPbI}_{3}$ deposited onto $\mathrm{ZnO}$, which was reported to quickly turn yellow, indicating a decomposition of the perovskite. ${ }^{30}$ However, in the XRD spectra shown in Figure 8(a), we

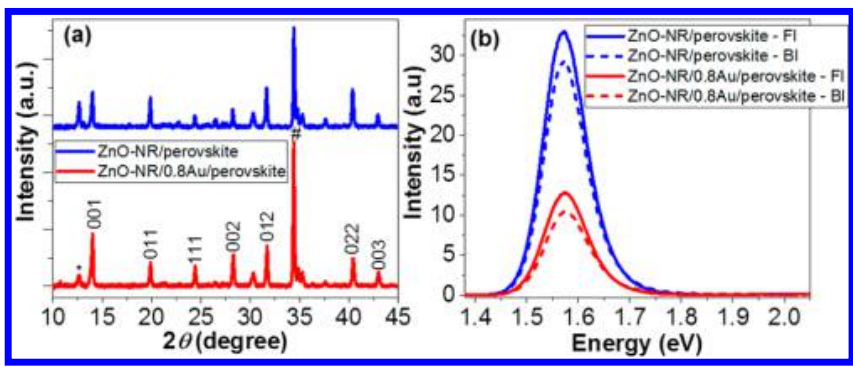

Figure 8. (a) XRD pattern of $\mathrm{ZnO}-\mathrm{NR} /$ perovskite (blue solid line) and $\mathrm{ZnO}-\mathrm{NR} / \mathrm{Au}-0.8 \mathrm{~nm} /$ perovskite (red solid line); the symbol \# represents the characteristic 002 peak from $\mathrm{ZnO}-\mathrm{NR}$, and the symbol * indicates the peak from $\mathrm{PbI}_{2}{ }^{4}$ (b) $\mathrm{PL}$ spectra of $\mathrm{ZnO}-\mathrm{NR} /$ perovskite (blue) and $\mathrm{ZnO}-\mathrm{NR} / 0.8 \mathrm{Au} /$ perovskite (red) under front illumination (FI, solid lines) and back illumination (BI, dashed lines), respectively.

observe that the intensity of the (001) peak of the perovskite is higher in samples containing $\mathrm{Au}$ nanoparticles, and furthermore, the peak at $2 \theta=12.7^{\circ}$, originating from $\mathrm{PbI}_{2}{ }^{4}$ is significantly lower here. Therefore, XRD suggests that $\mathrm{Au}$ suppresses the decomposition of perovskites into its constituents.
Figure $8(\mathrm{~b})$ shows the $\mathrm{PL}$ of the $\mathrm{ZnO}-\mathrm{NR} /$ perovskite (blue solid line) and the $\mathrm{ZnO}-\mathrm{NR} / 0.8 \mathrm{Au} /$ perovskite (red solid line) under "front illumination" (i.e., the perovskite layer faces both the excitation source and PL detector). We measured the PL spectra of the samples using an excitation wavelength of 2.64 $\mathrm{eV}$ to study the emission from the perovskite layer while avoiding excitation of the $\mathrm{ZnO}$ and $\mathrm{Au}$ nanoparticles. Selective excitation of the perovskite at $2.64 \mathrm{eV}$ is assumed based on the absorption spectra of the perovskites (see Figure S3(b)), compared to the $\mathrm{ZnO}$ and $\mathrm{Au}$ nanoparticles (see Figure S2(b)). We normalized the perovskite PL spectra to account for slight differences in the perovskite layer thickness by dividing by the fraction of absorbed photons $\left(F_{A}\right)$ at $2.64 \mathrm{eV}$, where $F_{A}$ is given by

$$
F_{A}=1-10^{A}
$$

and $A$ is absorbance. We observe a decrease in the PL emission intensity when the absorber (see Figure S3(b)) is interfaced with $\mathrm{ZnO}$ and a further decrease in PL emission when $\mathrm{Au}$ nanoparticles are introduced in the structures.

An excitation wavelength of $2.64 \mathrm{eV}$ is expected to lead to complete absorption of the excitation within the top $100 \mathrm{~nm}$ of the entire $800 \mathrm{~nm}$ perovskite layer. ${ }^{64}$ Hence, front illumination is expected to reveal recombination processes mainly at the perovskite top surface and perovskite bulk region. To probe recombination processes at the interface with the $\mathrm{ZnO}$ electrode, we additionally performed experiments under "back illumination" (i.e., both the excitation light and the perovskite $\mathrm{PL}$ are transmitted through the glass/ITO/ZnO layers at the back of the sample). This should lead to the perovskite being excited predominantly at the $\mathrm{ZnO}$ interface rather than the bulk. We note, however, that the PL under back illumination (dashed lines) is only slightly less intense than under front illumination (solid lines). Although the influence of both the $\mathrm{ZnO}$ and the $\mathrm{Au}$ nanoparticles on the perovskite $\mathrm{PL}$ intensity is significant, the geometry of the measurement is not. We attribute the similarity in the spectra to the high diffusion lengths of charge carriers in perovskite layers. This indicates that locating defect sites in perovskite films (i.e., front surface versus bulk versus back surface of the film) with PL measurements is nontrivial.

II.iii. Impedance Modeling and Capacitance Spectra of Solar Cells. Solar cells were prepared by depositing doped spiro-OMeTAD hole-transport layers and $\mathrm{Au}$ electrodes onto the $\mathrm{ZnO}-\mathrm{NR} /$ provskite and $\mathrm{ZnO}-\mathrm{NR} / 0.8 \mathrm{Au} /$ perovsite structures. Impedance spectroscopy was performed on the devices 

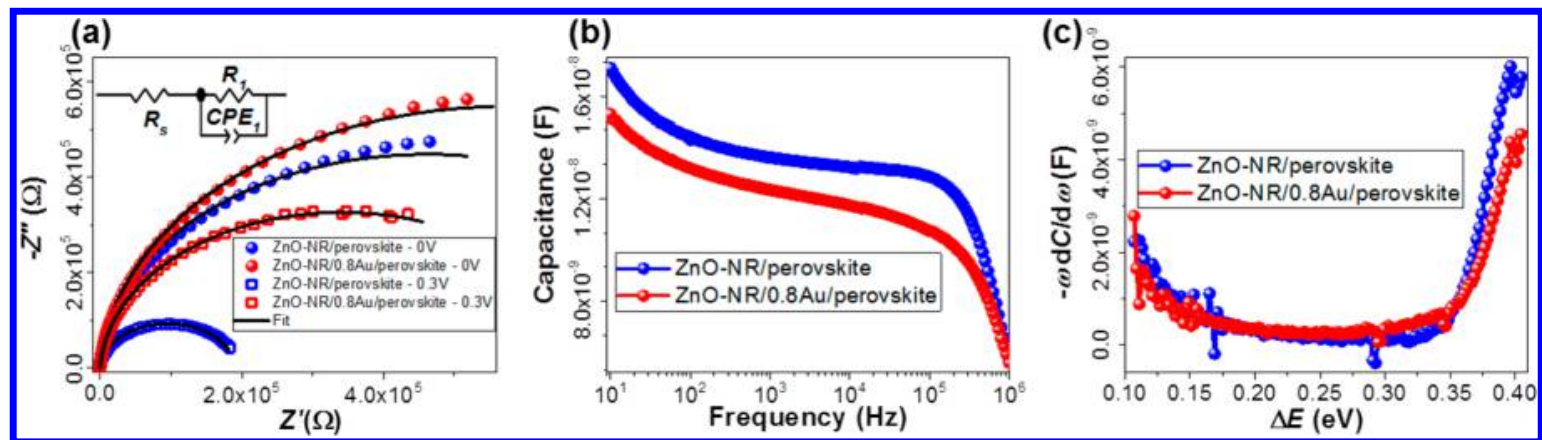

Figure 9. (a) Nyquist plot and fit of the impedance spectra from the $\mathrm{ZnO}-\mathrm{NR} /$ perovskite (blue) and $\mathrm{ZnO}-\mathrm{NR} / 0.8 \mathrm{Au} /$ perovskite (red) devices in the dark at DC bias voltages of 0 and $0.3 \mathrm{~V}$; the equivalent-circuit model $\left(R_{\mathrm{s}}-R_{1} C P E_{1}\right)$ in the inset was used to model the impedance spectra. (b) Capacitance-frequency $(C-f)$ spectra of $\mathrm{ZnO}-\mathrm{NR} /$ perovskite (blue) and $\mathrm{ZnO}-\mathrm{NR} / 0.8 \mathrm{Au} /$ perovskite (red) devices in the dark at a DC bias voltage of $0 \mathrm{~V}$. (c) $-\omega \frac{\mathrm{d} C}{\mathrm{~d} \omega}(\mathrm{t}-\mathrm{DOS})$ versus $\Delta E$ of $\mathrm{ZnO}-\mathrm{NR} /$ perovskite (blue) and $\mathrm{ZnO}-\mathrm{NR} / 0.8 \mathrm{Au} /$ perovskite (red) devices in the dark at a DC bias voltage of $0 \mathrm{~V}$.

Table 1. Summary of the Values of the Circuit Elements of the Devices

sample name and $\mathrm{DC}$ bias voltage
$\mathrm{ZnO}-\mathrm{NR} /$ perovskite $(0 \mathrm{~V})$
$\mathrm{ZnO}-\mathrm{NR} / 0.8 \mathrm{Au} /$ perovskite $(0 \mathrm{~V})$
$\mathrm{ZnO}-\mathrm{NR} /$ perovskite $(0.3 \mathrm{~V})$
$\mathrm{ZnO}-\mathrm{NR} / 0.8 \mathrm{Au} /$ perovskite $(0.3 \mathrm{~V})$

in the dark at DC bias voltages of 0 and $0.3 \mathrm{~V}$ to elucidate the influence of the Au nanoparticles on the electrical properties of the $\mathrm{ZnO} /$ perovskite interface. Figure 9(a) shows the Nyquist plots for the $\mathrm{ZnO}-\mathrm{NR} /$ perovskite (blue) and the $\mathrm{ZnO}-\mathrm{NR} /$ $0.8 \mathrm{Au} /$ perovskite (red) devices. We observe that the impedance $(Z)$ increases with addition of $\mathrm{Au}$ nanoparticles. We do not observe a signature of ionic conduction, typically resulting in a low-frequency tail in the spectrum. ${ }^{65}$

We modeled the impedance spectra with the equivalent circuit shown in the inset of Figure 9(a). The circuit consists of a series resistance $R_{\mathrm{s}}$ to account for contacting resistance and one resistor-capacitor $(R-C)$ element. The capacitor is modified to account for any dispersive (time-dependent) effects by introducing a constant-phase element (CPE). The impedance of the CPE $\left(Z_{\mathrm{CPE}}\right)$ is given by

$$
Z_{\mathrm{CPE}}=\frac{1}{Q(\mathrm{i} \omega)^{\alpha}}
$$

where $\omega$ is the angular frequency, $Q$ is a coefficient, and $\alpha$ is a unitless parameter between 0 and 1 that accounts for dispersion in the system. If $\alpha=1, \mathrm{CPE}$ reduces to an ideal capacitor with $Q=C$, and if $\alpha=0$, the CPE reduces to an ideal resistor with $Q=1 / R^{66}$

The values for the $R_{1}-C P E_{1}$ element are very comparable at 0 and $0.3 \mathrm{~V}$. We attribute this element to electrical processes at the $\mathrm{ZnO} /$ perovskite interface. As $\alpha \approx 1$, we set $Q=C$. Interestingly, the addition of $\mathrm{Au}$ nanoparticles significantly increases the resistance $R_{1}(922 \pm 8$ vs $1150 \pm 7 \mathrm{k} \Omega$ at $0 \mathrm{~V}$ and $191 \pm 1$ vs $682 \pm 4 \mathrm{k} \Omega$ at $0.3 \mathrm{~V}$, respectively) but only minimally decreases the capacitance $Q(16.4 \pm 0.1$ vs $16.3 \pm$ $0.1 \mathrm{nF}$ at $0 \mathrm{~V}$ and $18.4 \pm 0.1$ vs $18.3 \pm 0.1 \mathrm{nF}$ at $0.3 \mathrm{~V}$, respectively) and decreases $\alpha(0.98 \pm 0.01$ vs $0.97 \pm 0.01$ at 0 $\mathrm{V}$ and $0.99 \pm 0.01$ vs $0.97 \pm 0.01$ at $0.3 \mathrm{~V}$, respectively), as shown in Table 1 . The time constant $(\tau)$ of the relaxation process was calculated from the time constant of the circuit, given by

$\begin{array}{cccc}R_{1}(\mathrm{k} \Omega) & \mathrm{Q}_{1}(\mathrm{nF}) & \alpha_{1} & \tau(\mathrm{ms}) \\ 922 \pm 8 & 16.4 \pm 0.1 & 0.98 \pm 0.01 & 15 \\ 1150 \pm 7 & 16.3 \pm 0.1 & 0.97 \pm 0.01 & 19 \\ 191 \pm 1 & 18.4 \pm 0.1 & 0.99 \pm 0.01 & 4 \\ 682 \pm 4 & 18.3 \pm 0.1 & 0.97 \pm 0.01 & 12\end{array}$

$$
\tau=R_{1} C
$$

If $R_{1}$ is interpreted as the recombination resistance, then $\tau$ corresponds to carrier lifetime. ${ }^{67,68} \mathrm{ZnO}-\mathrm{NR} / \mathrm{Au}$ samples yielded higher values of $\tau$ than $\mathrm{ZnO}-\mathrm{NR}$ samples (15 vs 19 $\mathrm{ms}$ at $0 \mathrm{~V}$ and from $4 \mathrm{vs} 12 \mathrm{~ms}$ at $0.3 \mathrm{~V}$ ).

To gain more insight into these results, we investigate the defect distribution at the $\mathrm{ZnO} /$ perovskite interface. Figure 9(b) shows capacitance-frequency $(C-f)$ spectra at DC bias voltages of $0 \mathrm{~V}$ in the dark for the $\mathrm{ZnO}-\mathrm{NR} /$ perovskite (blue) and the $\mathrm{ZnO}-\mathrm{NR} / 0.8 \mathrm{Au} /$ perovskite (red) devices, respectively. We observe that adding $\mathrm{Au}$ results in a slight reduction in device capacitance over nearly the full frequency range, consistent with the results of the equivalent-circuit model.

To understand this more quantitatively, we examine the density of trap states ( $t$-DOS) in the devices. By applying the approach first introduced by Walter et al., ${ }^{69,70}$ we investigated the $\mathrm{t}$-DOS in the devices according to

$$
N_{T}\left(E_{\omega}\right)=-\frac{V_{\mathrm{bi}}}{q w k_{\mathrm{B}} T} \omega \frac{\mathrm{d} C}{\mathrm{~d} \omega}
$$

where

$$
E_{\omega}=k_{\mathrm{B}} T \ln \left(\frac{\omega_{0}}{\omega}\right)
$$

where $C$ is the capacitance, $\omega$ is the angular frequency, $\omega_{0}$ is the attempt-to-escape frequency, $q$ is the elementary charge, $k_{B}$ is Boltzmann's constant, $T$ is the temperature, $V_{\mathrm{bi}}$ is the built-in potential, and $w$ is the depletion width of the solar cell.

The model assumes that trap states located close to a characteristic demarcation energy will capture or emit charges with a characteristic frequency, thereby contributing to the frequency-dependence of the capacitance, and that the defect distribution is proportional to the derivative of device capacitance with respect to frequency. The demarcation energy is calculated from $\omega=\omega_{0}$ (i.e., the maximum frequency at which a defect at energy $E_{\omega}$ is charged or discharged by the $V_{\mathrm{ac}}$ 
signal). ${ }^{69}$ Features at low frequencies are attributed to shallow trap densities, and features at higher frequencies are attributed to deep trap densities. ${ }^{70}$

Figure $9(\mathrm{c})$ shows the plot of $-\omega \frac{\mathrm{d} C}{\mathrm{~d} \omega}$ as a function of $\Delta E$, where $\Delta E$ is given by

$$
\Delta E=E_{0}-E_{\omega}
$$

and

$$
E_{0}=k_{\mathrm{B}} T \ln \left(\omega_{0}\right)
$$

, of the $\mathrm{ZnO}-\mathrm{NR} /$ perovskite (blue) and the $\mathrm{ZnO}-\mathrm{NR} / 0.8 \mathrm{Au} /$ perovskite (red) devices. We observe that the t-DOS spectra show a deep trap state between $\Delta E=0.35 \mathrm{eV}$ and $\Delta E=0.4$ $\mathrm{eV}$. The $\mathrm{Au}$ nanoparticles appear to reduce the density of deep traps in this energy range. We also tentatively relate these results to the larger signal from $\mathrm{PbI}_{2}$ (see Figure $8(\mathrm{a})$ ) in the $\mathrm{ZnO}-\mathrm{NR} /$ perovskite device compared to the $\mathrm{ZnO}-\mathrm{NR} / 0.8 \mathrm{Au} /$ perovskite device (see Figure 5), in contrast to the suppressed surface defects on $\mathrm{ZnO}-\mathrm{NR} / 0.8 \mathrm{Au}$ (see Figure 2).

The impedance data in the dark confirm the conclusions drawn from the PL and XPS measurements: incorporation of $\mathrm{Au}$ nanoparticles in $\mathrm{ZnO}$ nanorods yields higher carrier lifetimes, lower capacitance (in agreement with the lower defect densities found in PL), and an increased resistance (possibly a fingerprint of the increased band bending inferred from XPS and UPS). Specifically, Au was found to reduce the trap density centered between 0.35 and $0.4 \mathrm{eV}$ (see Figure $9(\mathrm{c}))$. As the t-DOS analysis does not discriminate between positively or negatively charged defect sites, ${ }^{70}$ the trap density may be distributed above or below $E_{\mathrm{F}}$ in the bandgap. Depending on the nature of the trap sites and position in the bandgap, electron transfer between the $\mathrm{Au}$ nanoparticle and the perovskite or between the $\mathrm{Au}$ nanoparticle and $\mathrm{ZnO}-\mathrm{NR}$ may lead to passivation of this trap density. Additionally, an increase in the $E_{\mathrm{F}}$ at the heterostructure junction under illumination would promote trap filling.

II.iv. Solar-Cell Performance. Figure 10(a) shows the current density-voltage $(J-V)$ characteristics under illumina-

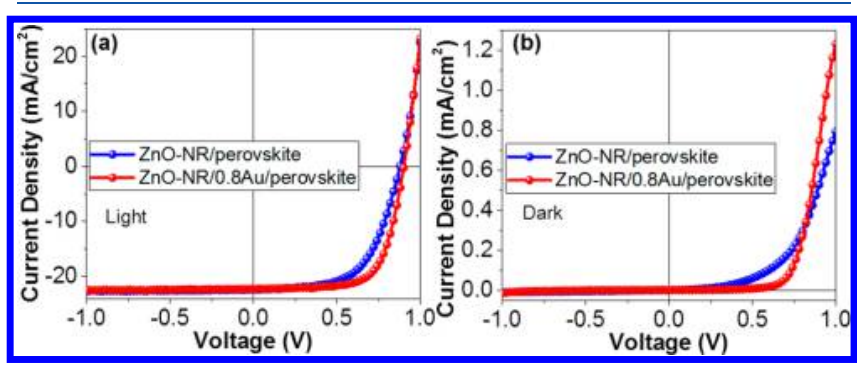

Figure 10. (a) $J-V$ characteristics under illumination for $\mathrm{ZnO}-\mathrm{NR} /$ perovskite (blue) and $\mathrm{ZnO}-\mathrm{NR} / 0.8 \mathrm{Au} /$ perovskite (red). (b) $J-V$ characteristics in the dark. All measurement was performed with a reverse scan (RS) at a scan rate of $182 \mathrm{mV} / \mathrm{s}$. tion for the $\mathrm{ZnO}-\mathrm{NR} /$ perovskite (blue) and the $\mathrm{ZnO}-\mathrm{NR}$ / $0.8 \mathrm{Au} /$ perovskite (red) devices with reverse scan (RS) at a scan rate of $182 \mathrm{mV} / \mathrm{s}$. Generally, we observe that the $\mathrm{ZnO}$ $\mathrm{NR} / 0.8 \mathrm{Au} /$ perovskite solar cells have higher power-conversion efficiencies (PCE) than the $\mathrm{ZnO}-\mathrm{NR} /$ perovskite solar cells. Specifically, devices prepared with $\mathrm{ZnO}-\mathrm{NR} / \mathrm{Au}$ vs $\mathrm{ZnO}$ ETL demonstrate higher open-circuit voltage $\left(V_{\text {oc }}\right)$ and fill factor (FF) values, leading to increased PCE. The PCEs of the solar cells were observed to increase from $11.5 \pm 0.2$ to $12.7 \pm 0.9 \%$, the $V_{\text {oc }}$ from $0.86 \pm 0.01$ to $0.92 \pm 0.04 \mathrm{~V}$, and the FF from $60.1 \pm 0.4$ to $62.8 \pm 3.5 \%$ upon the addition of $\mathrm{Au}$ nanoparticles. The short-circuit current density $\left(J_{\mathrm{sc}}\right)$ of the $\mathrm{ZnO}-\mathrm{NR} /$ perovskite devices is $22.1 \pm 0.3 \mathrm{~mA} / \mathrm{cm}^{2}$, and that of the $\mathrm{ZnO}-\mathrm{NR} / 0.8 \mathrm{Au} /$ perovskite devices is $22.2 \pm 0.1 \mathrm{~mA} / \mathrm{cm}^{2}$. We note that $J_{s c}$ is not influenced by the addition of $\mathrm{Au}$ nanoparticles. The solar-cell parameters (taken in reverse scan) are summarized in Table 2. Figure 10(b) shows the $J-V$ characteristics in the dark. We also observe a stark difference between the reverse scan (RS) and forward scan (FS) of the J$V$ characteristics of the devices (see Figure S4(b)); the addition of $\mathrm{Au}$ nanoparticles does not reduce the hysteresis effects. This indicates that hysteresis in the $J-V$ of the solar cells is not related to defects in the $\mathrm{ZnO}-\mathrm{NR}$.

The addition of $\mathrm{Au}$ nanoparticles on the $\mathrm{ZnO}$ nanorods electrodes lead to an increase in $V_{\text {oc }}, \mathrm{FF}$, and PCE of the solar cells under illumination, yet no increase in the $J_{s c}$ as would be expected for plasmonic enhancement. Instead, the improved PCE of the devices is consistent with reduced interfacial recombination at the electron-transport layer interface. $^{37,46,47,64}$ The increased FF and $V_{\text {oc }}$ originate from a better diode rectification, inferred from the $J-V$ curves in the dark (see Figure 10(b)), and point toward a critical role of defect-free electrode interfaces in photovoltaic cells. On the other hand, the typical hysteresis of perovskite solar cells seems unaffected by the presence of $\mathrm{Au}$ nanoparticles (see Figure S4(b)), suggesting the hysteresis to be a bulk perovskite phenomenon, at least in these devices.

II.v. Operational Stability of the Solar Cells. Figure 11 shows the time-dependent change in PCE, $V_{\text {oc }}$ FF, and $J_{\text {sc }}$ of the $\mathrm{ZnO}-\mathrm{NR} /$ perovskite (blue) and $\mathrm{ZnO}-\mathrm{NR} / 0.8 \mathrm{Au} /$ perovskite (red) devices under constant AM1.5 illumination. The performance of the $\mathrm{ZnO}-\mathrm{NR} / 0.8 \mathrm{Au} /$ perovskite device is initially higher but deteriorates more rapidly in these devices than for the $\mathrm{ZnO}-\mathrm{NR} /$ perovskite devices. This is primarily visible in the loss of $V_{\mathrm{oc}}$ and FF, resulting in a decrease in PCE. In contrast, the $V_{\text {oc }}$ of the $\mathrm{ZnO}-\mathrm{NR} /$ perovskite device even increases over time, consistent with the typically observed trap filling in metal oxides under light soaking. The lack of such positive light-soaking behavior in the $\mathrm{ZnO}-\mathrm{NR} / 0.8 \mathrm{Au} /$ perovskite devices supports our earlier hypothesis that the surface traps are already passivated by the Au particles, as light soaking does not influence performance in these devices.

Interestingly, the $\mathrm{Au}$ particles appear to stabilize the $J_{\mathrm{sc}}$ values, leading to less relative change in $J_{\mathrm{sc}}$ of the $\mathrm{ZnO}-\mathrm{NR} /$ $0.8 \mathrm{Au} /$ perovskite devices compared to that of the $\mathrm{ZnO}-\mathrm{NR} /$

Table 2. Solar-Cell Parameters Obtained for Both Device Architectures from Five Devices ${ }^{a}$

\begin{tabular}{lcccc}
\multicolumn{1}{c}{ sample name } & $J_{\mathrm{sc}}\left(\mathrm{mA} / \mathrm{cm}^{2}\right)$ & $V_{\mathrm{oc}}(\mathrm{V})$ & FF $(\%)$ & PCE $(\%)$ \\
$\mathrm{ZnO}-\mathrm{NR} /$ perovskite & $22.1 \pm 0.3(\mathbf{2 2 . 3})$ & $0.86 \pm 0.01(\mathbf{0 . 8 8})$ & $60.1 \pm 0.4(\mathbf{5 9 . 5})$ & $11.5 \pm 0.2(\mathbf{1 1 . 7 )}$ \\
$\mathrm{ZnO}-\mathrm{R} / 0.8 \mathrm{Au} /$ perovskite & $22.2 \pm 0.1(\mathbf{2 2 . 3})$ & $0.92 \pm 0.04(\mathbf{0 . 9 0})$ & $62.8 \pm 3.5(\mathbf{6 8 . 3})$ & $12.7 \pm 0.9(\mathbf{1 3 . 7})$
\end{tabular}

${ }^{a_{T}}$ The error is given by the standard deviations in the parameters. The parameters of the champion cell are given in parentheses. 


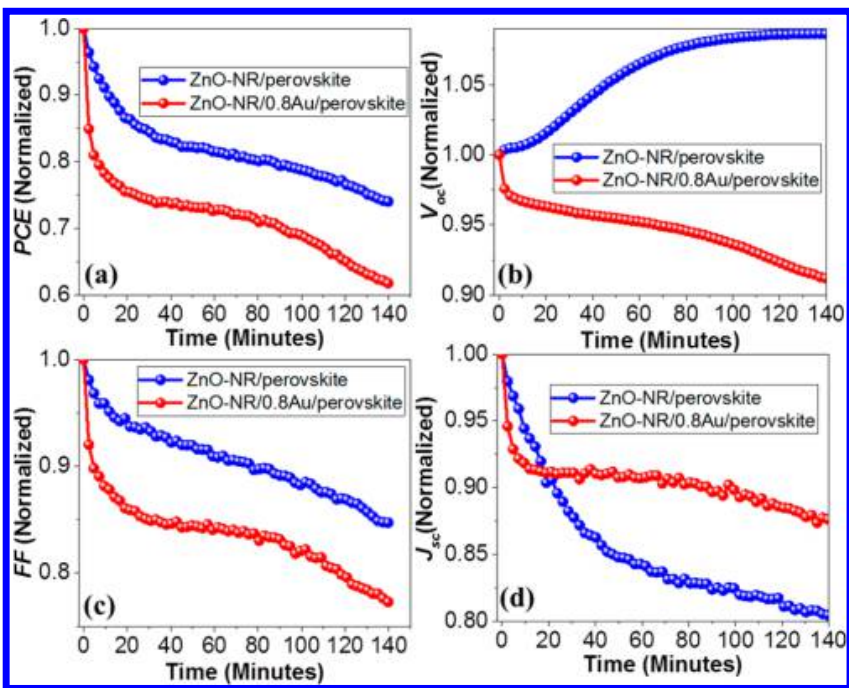

Figure 11. Change in the solar-cell parameters (a) PCE, (b) $V_{\text {oc }}$ (c) $\mathrm{FF}$, and (d) $J_{\mathrm{sc}}$ during light soaking under constant illumination of the $\mathrm{ZnO}-\mathrm{NR} /$ perovskite (blue) and the $\mathrm{ZnO}-\mathrm{NR} / 0.8 \mathrm{Au} /$ perovskite (red) devices.

perovskite devices. To investigate this behavior further, we extracted the series resistance $\left(R_{\mathrm{s}}\right)$, shunt resistance $\left(R_{\mathrm{SH}}\right)$, and saturation current $\left(J_{\mathrm{o}}\right)$ from the $J-V$ curves under constant illumination. Figure $12(\mathrm{a}-\mathrm{c})$ shows the time-dependent changes in $R_{\mathrm{s}}, R_{\mathrm{SH}}$, and $J_{\mathrm{o}}$. We observe that $R_{\mathrm{s}}$ increases and $R_{\mathrm{SH}}$ decreases under constant illumination for both device architectures. More notable is that $J_{\mathrm{o}}$ (see Figure 12(c)) increases roughly exponentially in the $\mathrm{ZnO}-\mathrm{NR} / 0.8 \mathrm{Au} /$ perovskite device, whereas $J_{\mathrm{o}}$ decreases roughly exponentially in the $\mathrm{ZnO}-\mathrm{NR} /$ perovskite device. This behavior is consistent with the increase in $V_{\text {oc }}$ in the $\mathrm{ZnO}-\mathrm{NR} /$ perovskite device and the decrease in $V_{\mathrm{oc}}$ in the $\mathrm{ZnO}-\mathrm{NR} / 0.8 \mathrm{Au} /$ perovskite device. We do not attribute this behavior to heating of the devices during measurement, which is negligible (see Figure S7(a)). Rather, it may indicate dynamic processes of the $\mathrm{ZnO}-\mathrm{NR} / \mathrm{Au} /$ perovskite interface. We note that the phenomena in our operational stability test are nearly reversible (see Figure S7(b)) and, hence, are better described by reversible light-soaking effects than degradation processes. ${ }^{46}$

\section{CONCLUSIONS}

We demonstrate a straightforward way to control surface defects on $\mathrm{ZnO}$ nanorods arrays with thermally deposited $\mathrm{Au}$ nanoparticles. Thermal deposition of Au nanoparticles enables the formation of small, evenly distributed nanoparticles with well-defined sizes $<10 \mathrm{~nm}$ while avoiding contamination and etching of the ZnO-NR. With a combination of PL, XPS, and UPS, we observe that the $\mathrm{Au}$ nanoparticles decrease the density of oxygen vacancies and $\mathrm{OH}$-related surface defects in the $\mathrm{ZnO}-\mathrm{NR}$. We discuss these results in terms of Au-induced band bending in surface-near regions of the ZnO-NR. Solar cells were fabricated by infiltrating mixed-cation and mixedhalide lead perovskite $\left(\mathrm{Cs}_{0.15} \mathrm{FA}_{0.85} \mathrm{PbI}_{2.75} \mathrm{Br}_{0.25}\right)$ layers into the $\mathrm{ZnO}$ nanorods. Impedance spectroscopy revealed a reduction in carrier recombination rates, corresponding to a reduction in the trap density in solar cells prepared with $\mathrm{ZnO}-\mathrm{NR} / \mathrm{Au}$ versus $\mathrm{ZnO}-\mathrm{NR}$ transport layers. Proof-of-concept solar cells demonstrated an increase in the open-circuit voltage and fill factor and, therefore, PCE. The Au nanoparticles, however, did not increase device stability, indicating that other effects may limit device lifetime.

\section{EXPERIMENTAL SECTION}

IV.i. Materials. Zinc acetate dihydrate (analysis grade) and hexamethylenetetramine (analysis grade) were purchased from Merck Chemicals and used as received. Zinc nitrate hexahydrate (reagent grade, purity 98\%), cesium iodide (CsI), spiro-OMeTAD (HPLC grade, purity 99\%), bis(trifluoromethane) sulfonimide lithium, chlorobenzene, ethanolamine (ACS reagent grade, purity >99\%), $\mathrm{N}, \mathrm{N}$-dimethylformamide (DMF), dimethyl sulfoxide (DMSO), 4-tertbutylpyridine (purity 96\%), acetonitrile, and acetone were purchased from Sigma-Aldrich and used as received. Formamidinium iodide (FAI) was purchased from Greatcell Solar (formerly Dyesol). Lead(II) iodide $\left(\mathrm{PbI}_{2}\right)$ and lead(II) bromide $\left(\mathrm{PbBr}_{2}\right)$ were purchased from TCI. Absolute ethanol was purchased from VWR Chemicals. Au (purity 99.99\%) was purchased from Cookson Drijfhout B.V.

IV.ii. Synthesis of ZnO Nanorods by Chemical Bath Deposition. $\mathrm{ZnO}$ seed layers were prepared using a sol-gel method on ITO sputtered glass substrates (Praezisions Glas \& Optic GmbH) with size of $(25 \pm 0.5) \times(25 \pm 0.5) \mathrm{mm}$ and thickness of $1.1 \pm 0.1$ $\mathrm{mm}$. ITO substrates were cleaned for $15 \mathrm{~min}$ in acetone, $15 \mathrm{~min}$ in ethanol, and finally $15 \mathrm{~min}$ in Milli-Q water $(18 \mathrm{M} \Omega \cdot \mathrm{cm})$. All cleaning steps were performed in an ultrasonic bath at room temperature. Finally, the substrates were dried by a nitrogen flux and exposed to UV/ozone (ProCleaner 220, Bioforce Nanoscience Inc.) for $15 \mathrm{~min}$. For the fabrication of $\mathrm{ZnO}$ seeds, solution with a $0.5 \mathrm{M}$ concentration of zinc acetate dihydrate and monoethanolamine (MEA) with a molar ratio of 1:1 in ethanol was prepared based on the recipe from Peukert et al. ${ }^{52}$ The mixture was put in an ultrasonic bath at $40{ }^{\circ} \mathrm{C}$ for $20 \mathrm{~min}$ and was kept stirring at $40{ }^{\circ} \mathrm{C}$ for an additional $20 \mathrm{~min}$. This step was repeated until a clear solution was obtained. The precursor solution was then allowed to cool to room temperature, and subsequently, 200 $\mu \mathrm{L}$ of solution was deposited on ITO glass substrate by spin-coating at $2000 \mathrm{rpm}$ for $30 \mathrm{~s}$. The film was then thermally annealed using a precision hot plate at $350{ }^{\circ} \mathrm{C}$ for $20 \mathrm{~min}$ in air.

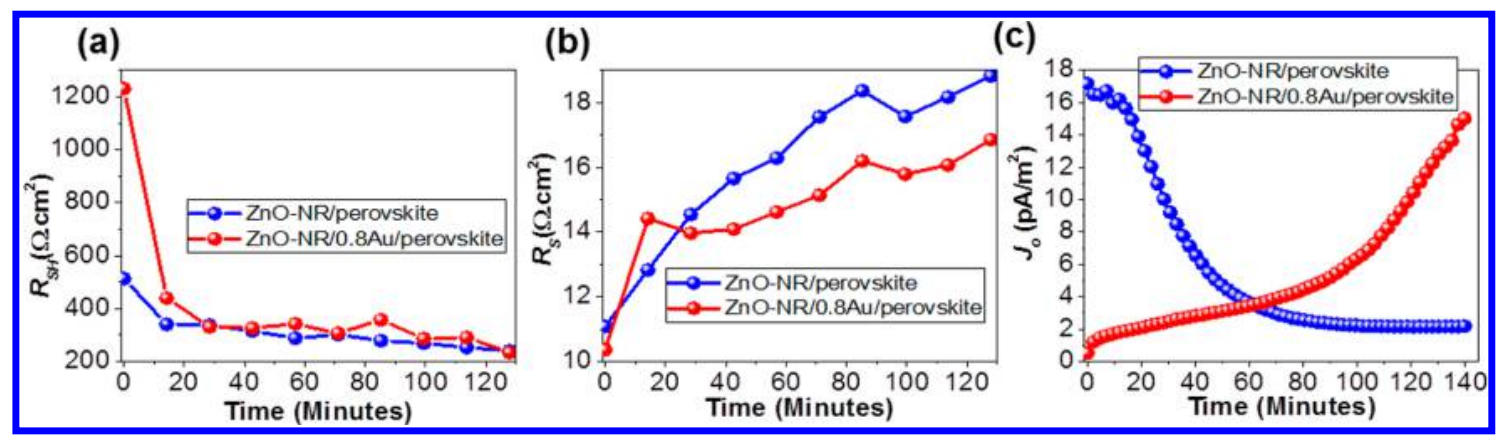

Figure 12. Change in the (a) $R_{\mathrm{SH}}$ (b) $R_{\mathrm{s}}$, and (c) Jo values during light soaking under constant illumination of the $\mathrm{ZnO}$-NR/perovskite (blue) and the $\mathrm{ZnO}-\mathrm{NR} / 0.8 \mathrm{Au} /$ perovskite (red) devices. 
$\mathrm{ZnO}-\mathrm{NR}$ were subsequently prepared by deposition in a solution of $25 \mathrm{mM}$ of zinc nitrate hexahydrate and $25 \mathrm{mM}$ hexamethylenetetramine (molar ratio 1:1) in Milli-Q water $(18 \mathrm{M} \Omega \cdot \mathrm{cm}){ }^{52}$ The solutions were prepared according the procedure below. First, zinc nitrate hexahydrate was dissolved in half of the total volume of the solution, which was followed by ultrasonification at room temperature for $5 \mathrm{~min}$. Then, hexamethylenetetramine was added to the second half of the solution, followed by ultrasonification at room temperature for $10 \mathrm{~min}$ and stirring on a hot plate at room temperature for $15 \mathrm{~min}$. Ultrasonification was performed again for $5 \mathrm{~min}$ at room temperature. This was followed by stirring on the hot plate at room temperature for $15 \mathrm{~min}$. ZnO-NR were grown at $80{ }^{\circ} \mathrm{C}$ for $60 \mathrm{~min}$. A $20 \mathrm{~mL}$ aliquot of solution was used for each substrate. The samples were then cleaned by Milli-Q water and dried using $\mathrm{N}_{2}$.

IV.iii. Deposition of Au Nanoparticles on ZnO Nanorods. To create the Au nanoparticles, a thin layer of Au was deposited on $\mathrm{ZnO}$ $\mathrm{NR}$ in a thermal evaporation chamber at $1 \times 10^{-6} \mathrm{mbar}$. The deposition rate was $0.1 \AA / \mathrm{s}$. The recorded thicknesses of the Au were $0.4,0.8$, and $1.2 \mathrm{~nm}$.

IV.iv. Preparation of Mixed-Cation and Mixed-Halide Lead Perovskite Layers. The perovskites $\left(\mathrm{Cs}_{0.15} \mathrm{FA}_{0.85} \mathrm{PbI}_{2.75} \mathrm{Br}_{0.25}\right)$ were prepared using $760 \mathrm{mg}$ of CsI, $2850 \mathrm{mg}$ of FAI, $8259 \mathrm{mg}$ of $\mathrm{PbI}_{2}$, and $895 \mathrm{mg}$ of $\mathrm{PbBr}_{2}$ in $13.5 \mathrm{~mL}$ of DMF and $1.5 \mathrm{~mL}$ of DMSO. The solutions were stirred at room temperature for a few hours in a $\mathrm{N}_{2}$ environment. The film was deposited by spin-coating $60 \mu \mathrm{L}$ of the solution on top $\mathrm{ZnO}-\mathrm{NR}$ and $\mathrm{ZnO}-\mathrm{NR} / 0.8 \mathrm{Au}$ at $1000 \mathrm{rpm}$ for $15 \mathrm{~s}$ and at $5000 \mathrm{rpm}$ for $45 \mathrm{~s}$. After $25 \mathrm{~s}$ of the spin-coating process, 210 $\mu \mathrm{L}$ of chlorobenzene was sprayed on the films. Then, the films were thermally annealed at $100{ }^{\circ} \mathrm{C}$ for $30 \mathrm{~min}$ in a $\mathrm{N}_{2}$ environment.

IV.v. Deposition of Doped Spiro-OMeTAD as the HoleTransport Layer. Spiro-OMeTAD $(80 \mathrm{mg})$ was dissolved in $1 \mathrm{~mL}$ of chlorobenzene. The solution was then stirred overnight. 4-tertButylpyridine $(28.5 \mu \mathrm{L})$ followed by $17.5 \mu \mathrm{L}$ of lithium bistrifluoromethanesulphonimidate solution $(520 \mathrm{mg}$ of lithium bistrifluoromethanesulphonimidate $/ 1 \mathrm{~mL}$ of acetonitrile) were then added to the solution. The solution was then stirred for $10 \mathrm{~min}$. A $50 \mu \mathrm{L}$ aliquot of the solution was deposited on top of the perovskite layer by spin-coating at $2000 \mathrm{rpm}$ for $60 \mathrm{~s}$. The sample was purged in $\mathrm{N}_{2}$ for $30 \mathrm{~min}$. The samples were then exposed for at least 1 night to ambient conditions in the dark.

IV.vi. Deposition of the Au Electrode. Finally, $100 \mathrm{~nm}$ of $\mathrm{Au}$ was deposited with a rate of $1 \AA / s$ onto the structures in a thermal evaporation chamber at $1 \times 10^{-6} \mathrm{mbar}$.

V.vii. Photoluminescence Spectroscopy. PL measurements were performed using a Cary Eclipse - Varian B.V. in ambient conditions. Measurements on $\mathrm{ZnO}-\mathrm{NR}$ and $\mathrm{ZnO}-\mathrm{NR} / \mathrm{Au}$ samples were performed with excitation at $4.43 \mathrm{eV}(280 \mathrm{~nm})$. Measurements were performed in ambient conditions with an excitation filter from 3.14 to $4.96 \mathrm{eV}$ and an emission filter from 1.23 to $3.44 \mathrm{eV}$.

$\mathrm{PL}$ measurements on $\mathrm{ZnO}-\mathrm{NR} /$ perovskite and $\mathrm{ZnO}-\mathrm{NR} / 0.8 \mathrm{Au} /$ perovskite structures were performed with excitation at $2.64 \mathrm{eV}$ (470 $\mathrm{nm}$ ), a scan range from 1.37 to $2.07 \mathrm{eV}$, filters for the excitation from 2.0 to $3.7 \mathrm{eV}$, and emission filters from 1.13 to $2.26 \mathrm{eV}$. The measurements were performed under both "front illumination" (with the perovskite layer facing the excitation source) and "back illumination" (via first the glass/ITO/ZnO-NR layer).

V.viii. Photoelectron Spectroscopy (XPS and UPS). The photoelectron spectroscopy measurements were performed at the Institute of Physical Chemistry, University of Cologne, Germany, in a custom-built UHV system using a Phoibos 100 hemispherical electron analyzer from Specs. The XPS was performed with an $\mathrm{Al} \mathrm{K} \alpha$ X-ray source (VG) at an excitation energy of $1253.6 \mathrm{eV}$, whereas UPS was performed with a He plasma lamp (VG Scienta) using the $\mathrm{He} \mathrm{II}_{\alpha}$ line at $40.8 \mathrm{eV}$. The relative peak intensities of XPS spectra were corrected by their relative sensitivity factors (RSF, 2.93 for O and 9 for $\mathrm{Zn}$ ).

V.ix. Impedance Spectroscopy. Impedance spectroscopy measurements were performed using a PGSTAT302N (Autolab, Metrohm) equipped with an impedance analyzer (FRA32M). The frequency range used was $1 \mathrm{MHz}-10 \mathrm{~Hz}$, and a $V_{\mathrm{ac}}$ amplitude of 10
$\mathrm{mV}$ was applied. The $\mathrm{DC}$ voltage was varied, and measurements were performed at $0,0.1,0.2$, and $0.3 \mathrm{~V}$ in the dark.

V.x. Current-Voltage Characterization. Current-voltage curves measurements were performed in a $\mathrm{N}_{2}$ environment. $J-V$ curves were obtained in the dark and under AM 1.5G of sun (100 $\mathrm{mW} / \mathrm{cm}^{2}$ ) illumination with a LOT solar simulator combined with a Keithley 2400 source meter controlled by a LabView program. We measured at a scan rate of $182 \mathrm{mV} / \mathrm{s}$ in the reverse scan (RS). Under illumination, a mask was used, and the effective active area was 0.16 $\mathrm{cm}^{2}$ for these measurements. In our measurements, we employed a delay time of $50 \mathrm{~ms}$ between setting the voltage and reading the voltage, an integration time of $20 \mathrm{~ms}$ for three cycles of reading the current, a precondition voltage of $1.2 \mathrm{~V}$ before the start of each measurement, a hold time of $11 \mathrm{~s}$, and a voltage step size of $22 \mathrm{mV}$. We also investigated the hysteresis by recording scans in both forward (FS) and reverse (RS) direction.

V.xi. Operational Stability Tests under Illumination. The operational stability tests were performed under AM 1.5G (100 mW/ $\mathrm{cm}^{2}$ ) illumination of a LOT solar simulator using a Keithley 2400 source meter controlled by a LabView program with a setup delay time of $50 \mathrm{~ms}$, integration time of $20 \mathrm{~ms}$ for three cycles, precondition voltage of $1.2 \mathrm{~V}$, hold time of $11 \mathrm{~s}$, and voltage step size of $22 \mathrm{mV}$ for the reverse scan. The measurements was performed every $2 \mathrm{~min}$ continuously.

\section{ASSOCIATED CONTENT}

\section{Supporting Information}

The Supporting Information is available free of charge on the ACS Publications website at DOI: 10.1021/acsaem.9b00452.

AFM image of $\mathrm{ZnO}$ seed layer; SEM images of cross section view of $\mathrm{ZnO}-\mathrm{NR}$; XRD pattern of the $\mathrm{ZnO}-\mathrm{NR}$ and the $\mathrm{ZnO}-\mathrm{NR} / 0.8 \mathrm{Au}$; the absorbance of the $\mathrm{ZnO}$ $\mathrm{NR}$ and the $\mathrm{ZnO}-\mathrm{NR} / 0.8 \mathrm{Au}$; absolute PL intensity of the $\mathrm{ZnO}-\mathrm{NR}, \mathrm{ZnO}-\mathrm{NR} / 0.4 \mathrm{Au}, \mathrm{ZnO}-\mathrm{NR} / 0.8 \mathrm{Au}, \mathrm{ZnO}$ $\mathrm{NR} / 1.2 \mathrm{Au}$; XRD pattern of the perovskites on glass substrate; the absorbance and PL of the perovskites on glass substrate; the absorbance of $\mathrm{ZnO}-\mathrm{NR} /$ perovskite and $\mathrm{ZnO}-\mathrm{NR} / 0.8 \mathrm{Au} /$ perovskite; the reverse scan (RS) and forward scan (FS) of the $J-V$ characteristics of the devices; Nyquist plots of impedance data taken from $\mathrm{ZnO}-\mathrm{NR} /$ perovskite and $\mathrm{ZnO}-\mathrm{NR} / 0.8 \mathrm{Au} /$ perovskite devices under the dark at bias voltages of 0.1 and 0.2 $\mathrm{V}$; capacitance-frequency $(C-f)$ spectra, in the dark at bias voltages of $0.1,0.2$, and $0.3 \mathrm{~V} ; J-V$ curve during stability test of $\mathrm{ZnO}-\mathrm{NR} /$ perovskite and $\mathrm{ZnO}-\mathrm{NR}$ / $0.8 \mathrm{Au} /$ perovskite solar cells; temperature versus time of stability test; reversibility of $J-V$ characteristics of the $\mathrm{ZnO}-\mathrm{NR} /$ perovskite and the $\mathrm{ZnO}-\mathrm{NR} / 0.8 \mathrm{Au} /$ perovskite solar-cell devices before and after light-soaking test; details for extraction of the saturation current from the $J-V$ data (PDF)

\section{AUTHOR INFORMATION}

\section{Corresponding Author}

*E-mail: e.l.von.hauff@vu.nl.

ORCID $\odot$

Selina Olthof: 0000-0002-8871-1549

Loreta A. Muscarella: 0000-0002-0559-4085

Yulia Galagan: 0000-0002-3637-5459

Simon Christian Boehme: 0000-0002-8399-5773

Elizabeth von Hauff: 0000-0002-6269-0540 


\section{Author Contributions}

All authors contributed to the writing of the manuscript. All authors have given approval to the final version of the manuscript.

\section{Notes}

The authors declare no competing financial interest.

\section{ACKNOWLEDGMENTS}

The authors thank Martin Slaman, Jan Rector, Saskia Kars, Alina Chanaewa, and Leo Polak for assistance and supporting the experiments. The authors thank Rinke J. Wijngaarden and Ivan Infante for discussion. T. acknowledges the Ministry of Research, Technology and Higher Education, the Republic of Indonesia for the scholarship Program for Research and Innovation in Science and Technology (RISET-Pro) World Bank Loan No. 8245-ID. T., E.v.H., and Y.G. acknowledge the COST Action Stable Next Generation Photovoltaics (Grant No. MP1307) for support. S.C.B. acknowledges The Netherlands Organization of Scientific Research (NWO) for financial support through the Innovational Research Incentive (Veni) Scheme (Grant No. 722.017.011). B.E. acknowledges The Netherlands Organization of Scientific Research (NWO) for financial support through the Innovational Research Incentive (Vidi).

\section{REFERENCES}

(1) Kojima, A.; Teshima, K.; Shirai, Y.; Miyasaka, T. Organometal Halide Perovskites as Visible-Light Sensitizers for Photovoltaic Cells. I. Am. Chem. Soc. 2009, 131, 6050-6051.

(2) Lee, M. M.; Teuscher, J.; Miyasaka, T.; Murakami, T. N.; Snaith, H. J. Efficient Hybrid Solar Cells Based on Meso-Superstructured Organometal Halide Perovskites. Science 2012, 338, 643-647.

(3) Yang, W. S.; Park, B. W.; Jung, E. H.; Jeon, N. J.; Kim, Y. C.; Lee, D. U.; Shin, S. S.; Seo, J.; Kim, E. K.; Noh, J. H.; Seok, S. Il. Iodide Management in Formamidinium-Lead-Halide-Based Perovskite Layers for Efficient Solar Cells. Science 2017, 356 (6345), 1376-1379.

(4) Saliba, M.; Matsui, T.; Seo, J.-Y.; Domanski, K.; Correa-Baena, J.-P.; Nazeeruddin, M. K.; Zakeeruddin, S. M.; Tress, W.; Abate, A.; Hagfeldt, A.; Grätzel, M. Cesium-Containing Triple Cation Perovskite Solar Cells: Improved Stability, Reproducibility and High Efficiency. Enerov Environ. Sci. 2016, 9 (6), 1989-1997.

(5) Leijtens, T.; Bush, K.; Cheacharoen, R.; Beal, R.; Bowring, A.; McGehee, M. D. Towards Enabling Stable Lead Halide Perovskite Solar Cells; Interplay Between Structural, Environmental, and Thermal Stability. I. Mater. Chem. A 2017, 5 (23), 11483-11500.

(6) McMeekin, D. P.; Sadoughi, G.; Rehman, W.; Eperon, G. E.; Saliba, M.; Horantner, M. T.; Haghighirad, A.; Sakai, N.; Korte, L.; Rech, B.; Johnston, M. B.; Herz, L. M.; Snaith, H. J. A Mixed-Cation Lead Mixed-Halide Perovskite Absorber for Tandem Solar Cells. Science 2016, 351 (6269), 151-155.

(7) Saliba, M.; Matsui, T.; Domanski, K.; Seo, J.-Y.; Ummadisingu, A.; Zakeeruddin, S. M.; Correa-Baena, J.-P.; Tress, W. R.; Abate, A.; Hagfeldt, A.; Gratzel, M. Incorporation of Rubidium Cations into Perovskite Solar Cells Improves Photovoltaic Performance. Science 2016, 354 (6309), 206-209.

(8) Rehman, W.; McMeekin, D. P.; Patel, J. B.; Milot, R. L.; Johnston, M. B.; Snaith, H. J.; Herz, L. M. Photovoltaic Mixed-Cation Lead Mixed-Halide Perovskites: Links Between Crystallinity, PhotoStability and Electronic Properties. Energy Environ. Sci. 2017, 10 (1), 361-369.

(9) Saliba, M.; Correa-Baena, J. P.; Wolff, C. M.; Stolterfoht, M.; Phung, N.; Albrecht, S.; Neher, D.; Abate, A. How to Make over 20\% Efficient Perovskite Solar Cells in Regular (n-i-p) and Inverted (p-i-n) Architectures. Chem. Mater. 2018, 30 (13), 4193-4201.

(10) Grancini, G.; Roldán-Carmona, C.; Zimmermann, I.; Mosconi, E.; Lee, X.; Martineau, D.; Narbey, S.; Oswald, F.; De Angelis, F.;
Graetzel, M.; Nazeeruddin, M. K. One-Year Stable Perovskite Solar Cells by 2D/3D Interface Engineering. Nat. Commun. 2017, 8, 15684.

(11) Peng, J.; Wu, Y.; Ye, W.; Jacobs, D. A.; Shen, H.; Fu, X.; Wan, Y.; Duong, T.; Wu, N.; Barugkin, C.; Nguyen, H. T.; Zhong, D.; Li, J.; Lu, T.; Liu, Y.; Lockrey, M. N.; Weber, K. J.; Catchpole, K. R.; White, T. P. Interface Passivation Using Ultrathin Polymer-Fullerene Films for High-Efficiency Perovskite Solar Cells with Negligible Hysteresis. Energy Environ. Sci. 2017, 10 (8), 1792-1800.

(12) Kegelmann, L.; Wolff, C. M.; Awino, C.; Lang, F.; Unger, E. L.; Korte, L.; Dittrich, T.; Neher, D.; Rech, B.; Albrecht, S. It Takes Two To Tango-Double-Layer Selective Contacts in Perovskite Solar Cells for Improved Device Performance and Reduced Hysteresis. ACS Appl. Mater. Interfaces 2017, 9 (20), 17245-17255.

(13) Turren-Cruz, S.-H.; Hagfeldt, A.; Saliba, M. MethylammoniumFree, High-Performance, and Stable Perovskite Solar Cells on a Planar Architecture. Science 2018, 362, 449-453.

(14) Wu, W. Q.; Chen, D.; Caruso, R. A.; Cheng, Y. B. Recent Progress in Hybrid Perovskite Solar Cells Based on n-type Materials. L. Mater. Chem. A 2017, 5 (21), 10092-10109.

(15) Correa-Baena, J. P.; Saliba, M.; Buonassisi, T.; Grätzel, M.; Abate, A.; Tress, W.; Hagfeldt, A. Promises and Challenges of Perovskite Solar Cells. Science 2017, 358 (6364), 739-744.

(16) Snaith, H. J. Present Status and Future Prospects of Perovskite Photovoltaics. Nat. Mater. 2018, 17, 372-376.

(17) Lira-Cantú, M. Perovskite Solar cells: Stability Lies at Interfaces. Nat. Energy 2017, 2, 17115.

(18) Chandiran, A. K.; Abdi-jalebi, M.; Nazeeruddin, M. K.; Grätzel, M. Analysis of Electron Transfer Properties of $\mathrm{ZnO}$ and $\mathrm{TiO}_{2}$ Photoanodes for Dye-Sensitized Solar Cells. ACS Nano 2014, 8 (3), 2261-2268.

(19) Zhang, Q.; Dandeneau, C. S.; Zhou, X.; Cao, Q. ZnO Nanostructures for Dye-Sensitized Solar Cells. Adv. Mater. 2009, 21, 4087-4108.

(20) Özgür, Ü.; Alivov, Y. I.; Liu, C.; Teke, A.; Reshchikov, M. A.; Doğan, S.; Avrutin, V.; Cho, S.; Morkoç, H. Comprehensive Review of $\mathrm{ZnO}$ Materials and Devices. I. Appl. Phvs. 2005, 98, 041301.

(21) Janotti, A.; Van De Walle, C. G. Fundamentals of Zinc Oxide as a Semiconductor. Rep. Prog. Phys. 2009, 72, 126501.

(22) Chen, R.; Cao, J.; Duan, Y.; Hui, Y.; Chuong, T. T.; Ou, D.; Han, F.; Cheng, F.; Huang, X.; Wu, B.; Zheng, N. High-Efficiency, Hysteresis-Less, UV-Stable Perovskite Solar Cells with Cascade ZnO-ZnS Electron Transport Laver. I. Am. Chem. Soc. 2019, 141, 541-547.

(23) Bi, D.; Boschloo, G.; Schwarzmuller, S.; Yang, L.; Johansson, E. M. J.; Hagfeldt, A. Efficient and Stable $\mathrm{CH}_{3} \mathrm{NH}_{3} \mathrm{PbI}_{3}$-Sensitized $\mathrm{ZnO}$ Nanorod Array Solid-State Solar Cells. Nanoscale 2013, 5, 1168611691.

(24) Son, D. Y.; Im, J. H.; Kim, H. S.; Park, N. G. 11\% Efficient Perovskite Solar Cell Based on ZnO Nanorods: An Effective Charge Collection System. I. Phvs. Chem. C 2014, 118 (30), 16567-16573.

(25) Son, D. Y.; Bae, K. H.; Kim, H. S.; Park, N. G. Effects of Seed Layer on Growth of $\mathrm{ZnO}$ Nanorod and Performance of Perovskite Solar Cell. I. Phvs. Chem. C 2015, 119 (19), 10321-10328.

(26) Yang, G.; Tao, H.; Qin, P.; Ke, W.; Fang, G. Recent Progress in Electron Transport Layers for Efficient Perovskite Solar Cells. I. Mater. Chem. A 2016, 4 (11), 3970-3990.

(27) Zhang, P.; Wu, J.; Zhang, T.; Wang, Y.; Liu, D.; Chen, H.; Ji, L.; Liu, C.; Ahmad, W.; Chen, Z. D.; Li, S. Perovskite Solar Cells with ZnO Electron-Transporting Materials. Adv. Mater. 2018, 30, 1703737.

(28) Zhang, H.; Cheng, J.; Lin, F.; He, H.; Mao, J.; Wong, K. S.; Jen, A. K. Y.; Choy, W. C. H. Pinhole-Free and Surface-Nanostructured $\mathrm{NiO}_{x}$ Film by Room-Temperature Solution Process for HighPerformance Flexible Perovskite Solar Cells with Good Stability and Reproducibility. ACS Nano 2016, 10, 1503-1511.

(29) Nimens, W. J.; Ogle, J.; Caruso, A.; Jonely, M.; Simon, C.; Smilgies, D.; Noriega, R.; Scarpulla, M.; Whittaker-brooks, L. Morphology and Optoelectronic Variations Underlying the Nature of the Electron Transport Layer in Perovskite Solar Cells. ACS Appl. Energy Mater. 2018, 1, 602-615. 
(30) Cheng, Y.; Yang, Q. D.; Xiao, J.; Xue, Q.; Li, H. W.; Guan, Z.; Yip, H. L.; Tsang, S. W. Decomposition of Organometal Halide Perovskite Films on Zinc Oxide Nanoparticles. ACS Appl. Mater. Interfaces 2015, 7 (36), 19986-19993.

(31) Sin, D. H.; Jo, S. B.; Lee, S. G.; Ko, H.; Kim, M.; Lee, H.; Cho, $\mathrm{K}$. Enhancing the Durability and Carrier Selectivity of Perovskite Solar Cells Using a Blend Interlayer. ACS Appl. Mater. Interfaces 2017, 9 (21), 18103-18112.

(32) Janotti, A.; Van De Walle, C. G. Native Point Defects in ZnO. Phys. Rev. B: Condens. Matter Mater. Phvs. 2007, 76, 165202.

(33) Trost, S.; Becker, T.; Zilberberg, K.; Behrendt, A.; Polywka, A.; Heiderhoff, R.; Görrn, P.; Riedl, T. Plasmonically Sensitized MetalOxide Electron Extraction Layers for Organic Solar Cells. Sci. Rep. 2015, 5, 7765 .

(34) Bora, T.; Kyaw, H. H.; Sarkar, S.; Pal, S. K.; Dutta, J. Highly Efficient Zno/Au Schottky Barrier Dye-Sensitized Solar Cells: Role of Gold Nanoparticles on the Charge-Transfer Process. Beilstein I. Nanotechnol. 2011, 2 (1), 681-690.

(35) Lee, D. S.; Kim, W.; Cha, B. G.; Kwon, J.; Kim, S. J.; Kim, M.; Kim, J.; Wang, D. H.; Park, J. H. Self-Position of Au NPs in Perovskite Solar Cells: Optical and Electrical Contribution. ACS Appl. Mater. Interfaces 2016, 8 (1), 449-454.

(36) Carretero-Palacios, S.; Jiménez-Solano, A.; Míguez, H. Plasmonic Nanoparticles as Light-Harvesting Enhancers in Perovskite Solar Cells: A User's Guide. ACS Energy Lett. 2016, 1 (1), 323-331.

(37) Kamat, P. V. Quantum Dot Solar Cells. Semiconductor Nanocrystals as Light Harvesters. I. Phvs. Chem. C 2008, 112 (48), 18737-18753.

(38) Wood, A.; Giersig, M.; Mulvaney, P. Fermi Level Equilibration in Quantum Dot-Metal Nanojunctions. I. Phvs. Chem. B 2001, 105 (37), 8810-8815.

(39) Subramanian, V.; Wolf, E. E.; Kamat, P. V. Green Emission to Probe Photoinduced Charging Events in $\mathrm{ZnO}-\mathrm{Au}$ Nanoparticles. Charge Distribution and Fermi-Level Equilibration. I. Phvs. Chem. B 2003, 107 (30), 7479-7485.

(40) Haruta, M. Size and Support Dependency in the Catalysis of Gold. Catal. Todav 1997, 36, 153-166.

(41) Liu, K.; Sakurai, M.; Liao, M.; Aono, M. Giant Improvement of The Performance of $\mathrm{ZnO}$ Nanowire Photodetectors by Au Nanoparticles. I. Phvs. Chem. C 2010, 114 (46), 19835-19839.

(42) Ruiz Peralta, M. D. L.; Pal, U.; Zeferino, R. S. Photoluminescence (PL) Quenching and Enhanced Photocatalytic Activity of Au-Decorated $\mathrm{ZnO}$ Nanorods Fabricated through MicrowaveAssisted Chemical Synthesis. ACS Appl. Mater. Interfaces 2012, 4, 4807-4816.

(43) Chen, Z. H.; Tang, Y. B.; Liu, C. P.; Leung, Y. H.; Yuan, G. D.; Chen, L. M.; Wang, Y. Q.; Bello, I.; Zapien, J. A.; Zhang, W. J.; Lee, C. S.; Lee, S. T. Vertically Aligned $\{\mathrm{ZnO}\}$ Nanorod Arrays Sentisized with Gold Nanoparticles for Schottky Barrier Photovoltaic Cells. I. Phvs. Chem. C 2009, 113 (30), 13433-13437.

(44) Park, S.; Mun, Y.; An, S.; In Lee, W.; Lee, C. Enhanced photoluminescence of $\mathrm{Au}$-functionalized $\mathrm{ZnO}$ nanorods annealed in a hydrogen atmosphere. I. Lumin. 2014, 147, 5-8.

(45) Wu, M.; Chen, W. J.; Shen, Y. H.; Huang, F. Z.; Li, C. H.; Li, S. K. In situ Growth of Match-like $\mathrm{ZnO} / \mathrm{Au}$ Plasmonic Heterostructure for Enhanced Photoelectrochemical Water Splitting. ACS Appl. Mater. Interfaces 2014, 6, 15052-15060.

(46) Ehrler, B.; Musselman, K. P.; Bohm, M. L.; Morgenstern, F. S. F.; Vaynzof, Y.; Walker, B. J.; MacManus-Driscoll, J. L.; Greenham, N. C. Preventing Interfacial Recombination in Colloidal Quantum Dot Solar Cells by Doping the Metal Oxide. ACS Nano 2013, 7 (5), 4210-4220.

(47) Ruf, T.; Repp, S.; Urban, J.; Thomann, R.; Erdem, E. Competing effects between intrinsic and extrinsic defects in pure and Mn-doped $\mathrm{ZnO}$ nanocrystals. I. Nanopart. Res. 2016, 18, 109.

(48) Qiu, W.; Ray, A.; Jaysankar, M.; Merckx, T.; Bastos, J. P.; Cheyns, D.; Gehlhaar, R.; Poortmans, J.; Heremans, P. An Interdiffusion Method for Highly Performing Cesium/Formamidi- nium Double Cation Perovskites. Adv. Funct. Mater. 2017, 27, 1700920.

(49) Lee, J. W.; Kim, D. H.; Kim, H. S.; Seo, S. W.; Cho, S. M.; Park, N. G. Formamidinium and Cesium Hybridization for Photo- and Moisture-Stable Perovskite Solar Cell. Adv. Energy Mater. 2015, 5, 1501310.

(50) Brillson, L. J.; Mosbacker, H. L.; Hetzer, M. J.; Strzhemechny, Y.; Look, D. C.; Cantwell, G.; Zhang, J.; Song, J. J. Surface and NearSurface Passivation, Chemical Reaction, and Schottky Barrier Formation at Zno Surfaces and Interfaces. Appl. Surf. Sci. 2008, 254 (24), 8000-8004.

(51) Brillson, L. J.; Mosbacker, H. L.; Hetzer, M. J.; Strzhemechny, Y.; Jessen, G. H.; Look, D. C.; Cantwell, G.; Zhang, J.; Song, J. J. Dominant Effect of Near-Interface Native Point Defects on $\mathrm{ZnO}$ Schottky Barriers. Appl. Phvs. Lett. 2007, 90, 102116.

(52) Peukert, A.; Vaillant Roca, L.; Scherer, M.; Lovrincic, R.; Ramanan, C.; Chanaewa, A.; Von Hauff, E. Controlled Morphology of $\mathrm{ZnO}$ Nanorods for Electron Transport in Squaraine Bulk-Hetero Junction Solar Cells With Thick Active Layers. Sol. RRL. 2017, 1, 1700132.

(53) McPeak, K. M.; Le, T. P.; Britton, N. G.; Nickolov, Z. S.; Elabd, Y. A.; Baxter, J. B. Chemical Bath Deposition of $\mathrm{ZnO}$ Nanowires at Near-Neutral pH Conditions Without Hexamethylenetetramine (HMTA): Understanding the Role Of HMTA in $\mathrm{ZnO}$ Nanowire Growth. Langmuir 2011, 27 (7), 3672-3677.

(54) Strano, V.; Urso, R. G.; Scuderi, M.; Iwu, K. O.; Simone, F.; Ciliberto, E.; Spinella, C.; Mirabella, S. Double Role of HMTA in $\mathrm{ZnO}$ Nanorods Grown by Chemical Bath Deposition. I. Phvs. Chem. C 2014, 118 (48), 28189-28195.

(55) Barbagiovanni, E. G.; Strano, V.; Franzò, G.; Crupi, I.; Mirabella, S. Photoluminescence Transient Study of Surface Defects in $\mathrm{ZnO}$ Nanorods Grown by Chemical Bath Deposition. Appl. Phvs. Lett. 2015, 106, 093108.

(56) Barbagiovanni, E. G.; Strano, V.; Franzò, G.; Reitano, R.; Dahiya, A. S.; Poulin-Vittrant, G.; Alquier, D.; Mirabella, S. Universal Model for Defect- Related Visible Luminescence in $\mathrm{ZnO}$ Nanorods. RSC Adv. 2016, 6 (77), 73170-73175.

(57) Barbagiovanni, E. G.; Reitano, R.; Franzò, G.; Strano, V.; Terrasi, A.; Mirabella, S. Radiative Mechanism and Surface Modification of Four Visible Deep Level Defect States in $\mathrm{ZnO}$ Nanorods. Nanoscale 2016, 8 (2), 995-1006.

(58) Vempati, S.; Mitra, J.; Dawson, P. One-Step Synthesis of ZnO Nanosheets: A Blue-White Fluorophore. Nanoscale Res. Lett. 2012, 7, 470 .

(59) Van Dijken, A.; Meulenkamp, E. A.; Vanmaekelbergh, D.; Meijerink, A. Luminescence of Nanocrystalline ZnO Particles: The Mechanism of The Ultraviolet and Visible Emission. L. Lumin. 2000, $87,454-456$.

(60) Azpiroz, J. M.; Infante, I.; Lopez, X.; Ugalde, J. M.; De Angelis, F. A First-Principles Study of II-VI (II 1 Zn; VI 1 O, S, Se, Te) Semiconductor Nanostructures. I. Mater. Chem. 2012, 22, 21453.

(61) Xu, H.; Dong, L.; Shi, X. Q.; Van Hove, M. A.; Ho, W. K.; Lin, N.; Wu, H. S.; Tong, S. Y. Stabilizing Forces Acting on ZnO Polar Surfaces : STM, LEED, and DFT. Phvs. Rev. B: Condens. Matter Mater. Phvs. 2014, 89, 235403.

(62) Winkler, S.; Frisch, J.; Amsalem, P.; Krause, S.; Timpel, M.; Stolte, M.; Würthner, F.; Koch, N. Impact of Molecular Dipole Moments on Fermi Level Pinning in Thin Films. I. Phvs. Chem. C 2014, 118, 11731-11737.

(63) Lien, D. H.; Durán Retamal, J. R.; Ke, J. J.; Kang, C. F.; He, J. H. Surface Effects in Metal Oxide-Based Nanodevices. Nanoscale 2015, 7 (47), 19874-19884.

(64) Shao, Y.; Xiao, Z.; Bi, C.; Yuan, Y.; Huang, J. Origin and Elimination of Photocurrent Hysteresis by Fullerene Passivation in $\mathrm{CH}_{3} \mathrm{NH}_{3} \mathrm{PbI}_{3}$ Planar Heterojunction Solar Cells. Nat. Commun. 2014, 5,5784 .

(65) Guerrero, A.; Garcia-Belmonte, G.; Mora-Sero, I.; Bisquert, J.; Kang, Y. S.; Jacobsson, T. J.; Correa-Baena, J. P.; Hagfeldt, A. Properties of Contact and Bulk Impedances in Hybrid Lead Halide 
Perovskite Solar Cells Including Inductive Loop Elements. I. Phvs. Chem. C 2016, 120 (15), 8023-8032.

(66) Ecker, B.; Egelhaaf, H.; Steim, R.; Parisi, J.; Von Hauff, E. Understanding S-Shaped Current-Voltage Characteristics in Organic Solar Cells Containing a $\mathrm{TiO}_{\mathrm{x}}$ Interlayer with Impedance Spectroscopy and Equivalent Circuit Analysis. L. Phys. Chem. C 2012, 116, 16333-16337.

(67) Goossens, A.; Schoonman, J. The Impedance of Surface Recombination at Illuminated Semiconductor Electrodes. I. Electroanal. Chem. Interfacial Electrochem. 1990, 289, 11-27.

(68) Fabregat-Santiago, F.; Garcia-Belmonte, G.; Mora-Seró, I.; Bisquert, J. Characterization of Nanostructured Hybrid and Organic Solar cells by Impedance Spectroscopy. Phvs. Chem. Chem. Phvs. 2011, 13, 9083-9118.

(69) Walter, T.; Herberholz, R.; Müller, C.; Schock, H. W. Determination of Defect Distributions from Admittance Measurements and Application to $\mathrm{Cu}(\mathrm{In}, \mathrm{Ga}) \mathrm{Se}_{2}$ Based Heterojunctions. I. Appl. Phvs. 1996, 80 (8), 4411-4420.

(70) Chanaewa, A.; Poulsen, K.; Gräfe, A.; Gimmler, C.; Von Hauff, E. Trap-Induced Dispersive Transport and Dielectric Loss in PbS Nanoparticle Films. Z. Phys. Chem. 2017, 231 (1), 121-134. 